NBSIR. 74.472

Analysis of Railroad Wheel Failure Derailment at Richmond Hill, New York, March 10, 1973

C. G. Interrante and G. E. Hicho

Mechanical Properties Section Metallurgy Division

Institute for Materials Research

National Bureau of Standards

Washington, O. C. 20234

April 1974

Failure Analysis Report

Prepared for

Federal Railroad Administration

Department of Transportation

Washington, D. C. 20590 



\title{
ANALYSIS OF RAILROAD WHEEL FAILURE - DERAILMENT AT RICHMOND HILL, NEII YORK, MARCH 10, 1973
}

\author{
C. G. Interrante and G. E. Hicho
}

Mechanical Properties Section

Metallurgy Division

Institute for Materials Research

National Bureau of Standards

Washington, D. C. 20234

April 1974

Failure Analysis Report

"This document has been prepared for the use of the Federal Railroad Administration, Department of Transportation, Washington, D. C. Responsibility for its further use rests with that agency. NBS requests that if release to the general public is contemplated, such action be taken only after consultation with the Office of Public Affairs at the National Bureau of Standards.

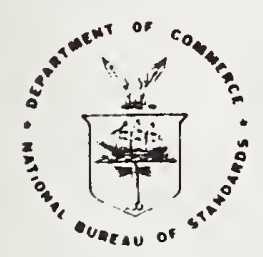

U. S. DEPARTMENT OF COMMERCE, Frederick B. Dent, Secretary NATIONAL BUREAU OF STANDARDS, Richard W. Roberts, Director 



\section{TABLE OF CONTENTS}

Page

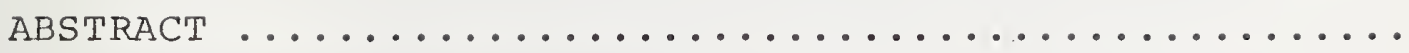

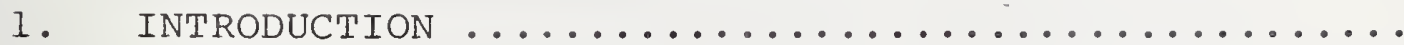

2. PURPOSE $\ldots \ldots \ldots \ldots \ldots \ldots \ldots \ldots \ldots \ldots \ldots \ldots \ldots \ldots \ldots \ldots \ldots \ldots \ldots \ldots$

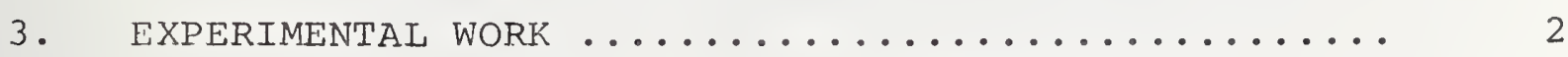

3.1 Sectioning of the sample $\ldots \ldots \ldots \ldots \ldots \ldots \ldots \ldots$

3.2 Dimensional Measurements ................ 3

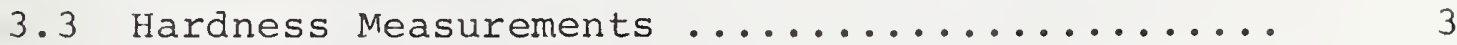

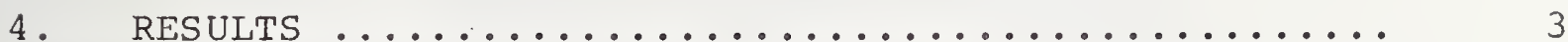

4.1 Macroscopic Observations .................. 3

4.2 Hardness Measurements .................... 4

4.3 Dimensional Measurements ................. 5

4.4 Chemical Composition .................. 5

4.5 Metallographic Examinations ............... 5

4.6 Fractographic Examinations ................ 6

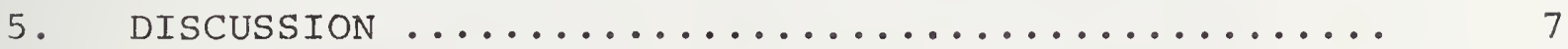

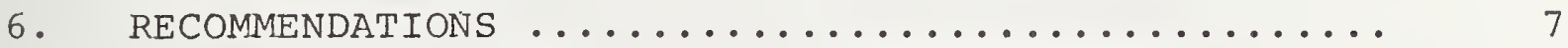

\section{TABLES}

1. Comparison of the Dimensions Specified by AAR and the Measured Values Taken from the Failed Wheel.

2. Chemical Composition of the Sample Taken from the Hub. 
1. Radial-Circumferential section of the Fractured Wheel, As Received at NBS.

2. Fractured Wheel Section Showing the Three Parts Into Which It Was Saw cut.

3. Locations of Replicas, A Through M, Taken on the Fracture Face.

4. Schematic Representation of the Location of Brinell Hardness Impressions and Equivalent Rockwell C Values (in parenthesis).

5. Photograph of Section 2 Showing the Brinell and Rockwe11 C Haraness Impressions, the Etched Sample, and the Saw Cut Between Pieces $2 \mathrm{~A}$ and $2 \mathrm{~B}$.

6. Results of Rockwell C Hardness Measurements Taken on Section 2 .

7. Color Photographs of the Fracture Face of the Rim Showing the Location of the Thermal Crack (Initiation Site).

8. Thermal Checks observed on the Tread of Section 2 After Hot Etching in 1:1 $\mathrm{HCl}$.

9. Photomicrographs Taken at Region C (Figure 5) Showing the Unaffected Base Metal of the Rim.

10. Photomicrographs Taken at Region B (Figure 5) Near the Inside of the HAZ Boundary.

11. Photomicrographs Taken at Region A (Figure 5) Showing the Coarse-Grained Heat-Affected Zone observed Near the Tread.

12. SEM Fractographs Taken at Location C of Figure 3, Showing the Predominately Quasi-Cleavage Fracture Mode observed in the Rim.

13. SEM Stereo-Pair Fractograph Taken at Location I of Figure 3, Showing the Pracominately QuasiCleavage Fracture Mode Observed in the Rim. 


\section{FIGURES}

14. SEM Fractographs Taken at Location A of Figure 3, Showing Quasi-Cleavage Fracture and Oxide Formations Observed Near the Boundary of the Heat-Affected zone of the Rim.

15 .

SEM Fractographs Taken from the Thermal Crack Region (15a) and from the Hub Region (15b), Showing Oxide Formations, Abraided Parts, and Flat Fracture.

APPENDIX A - Specification: AAR-M-1079-69.

APPENDIX B - Specification: AAR Dimensions for steel wheel of Design $A-40$ and Permissible Variations in Dimensions not shown by Tolerances of Individual Design Sheets. 


\section{ABSTRACT}

At the request of the Standards and Procedures Division, Federal Railroad Administration, Department of Transportation, a failure analysis was made of a section of a railroad wheel which had reportedly failed in service and had led to a derailment at Richmond Hill, New York. A section of the failed wheel was sent to NBS where it was examined and measurements made to determine the cause of the failure and to determine whether or not the wheel had been produced in accordance with applicable specifications.

The chemical composition, hardness, and dimensions of the wheel section were measured. The results indicate that the wheel met the requirements of the specifications. These measurements and other observations indicate that the failure occurred as a result of local overheating at the front of the tread. It is believed that this overheating occurred in service and resulted in the formation of a thermal crack in this region. This crack subsequently propagated rapidly in a radial direction through to the hub of the wheel. 
Analysis of Railroad Wheel Failure - Derailment at Richmond Hill, New York, March 10, 1973

\section{INTRODUCTION}

A failure analysis of a section of a railroad wheel, which failed in service and led to a derailment, was requested by the standards and Procedures Division, Federal Railroad Administration, Department of Transportation. The wheel sample was reported* to have been taken from a dieselelectric control unit, No. 609. This control unit, which was the last unit of a passenger train, was derailed at Richmond Hill, New York near the Dunton Tower on March 10 , 1973 at 12:45 a.m. The derailment was apparently due to the failure of this wheel.

Railroad investigators concluded* that the wheel had broken from the rim to the hub, with a measured separation of the rim of approximately $3 / 16$ inch. This fracture apparently permitted the wheel to move inward on the axle, approximately 4 inches, thereby allowing the wheel to drop from the rail. The wheel was reported to have been mounted on the control unit in october, 1972, and it had been in service for approximately 12,000 miles when the failure occurred. The temperature at the nearest U.S. Weather Bureau site, LaGuardia Airport, was reported to be $45^{\circ} \mathrm{F}$ at 10 p.m. on March 9, 1973, and $40^{\circ} \mathrm{F}$ at 1 a.m. on March 10, 1973.

A radial-circumferential section was torch cut from the failed wheel and sent to the National Bureau of Standards (NBS) for failure analyses. This section contained one of the two radial-axial faces of the fracture, as is shown in Figure 1.

The wheel was reported to have been produced in accordance with the Association of American Railroad (AAR) Specification M-107-69, for wrought, carbon steel wheels, and it was located at the left No. 2 wheel position on the diesel-control unit. The identification marking on the wheel (E) 74482 (B), indicated that it had been produced as Class B, rim treated. The wheel was of design $A-40$.**

* Letter dated April 3, 1973 from R. E. Black, District Inspector FRA, to C. R. Meyrick, Regional Director, FRA.

** Reported to Mr. G. E. Hicho (NBS) by Mr. J. Sharp of FRA in phone conversation October 4, 1973. 


\section{PURPOSE}

The objectives of this failure analysis were (1) to determine the condition of the wheel in respect to the specifications, to which it was produced, (2) to analyze the fracture face so as to determine, if possible, the initiation site of the fracture, and (3) to describe the propagation behavior, as observed on the fracture face. Another objective was to conduct tests deemed necessary to obtain background information concerning the overall question of the suitability of this steel for this application.

\section{EXPERIMENTAL WORK}

Measurements were made of the dimensions, the hardness, and the chemical composition of selected parts of the submitted sample, and the measured values were compared with the NAR Specifications of designation "M-107-69 for Wheels, Wrought Carbon Steel" to which the wheel had been produced.* In addition, macroscopic and microscopic observations were made on the wheel section submitted and on parts that were saw cut from it.

\subsection{Sectioning of the Sample}

The as-received wheel section was saw cut into three major parts, as shown in Figure 2. Section 1 contains the entire radial-axial face of the fracture. It was visually examined with the unaided eye and with the aid of a stereomicroscope at magnifications up to X3. Selected locations (A through $M$ in Figure 3) of the fracture surface were then replicated with cellulose acetate. The replicas were used for scanning-electron-microscope (SEM) examinations of the fracture surface. Replicas taken from A, C, D, L, and M were considered sufficient for characterizing the fracture surface and the other replicas therefore were not examined.

The remaining part of the sample (with the fracture face removed) contained a smooth, saw-cut surface. This surface was placed flat onto cardboard and the shape of the wheel section was obtained by tracing the outline. This tracing was useful in determining some of the dimensions of the wheel. Where possible, these measurements were checked by measurements taken directly from the wheel section. 
After the dimensional measurements were taken, the wheel section was further sectioned (saw cut) along the line that divides sections 2 and 3 , as shown in Figure 2. A 1-inch slice, taken from the front of the hub as shown in Figures 2 and 3 , was used for determinations of the chemical composition of the wheel. Section 2 was used for making hardness measurements, and for microscopic and macroscopic studies of the rim.

\subsection{Dimensional Measurements}

The measurements of the dimensions taken from the wheel section and from the tracing made from it are shown in Table 1, along with the AAR Specifications on dimensions for design A-40 wheels. We note that: (1) dimensions $0_{1}$ and $0_{2}$ were calculated from an assumed value of 10-3/4 inches for the bore, and (2) the reasured values $R_{1}$ and $R_{2}$ do not represent the values of the wheel in service, because these values were taken on a wheel section and the act of sectioning affects these dimensions.

\subsection{Hardness Measurements}

Brinell hardness measurements were made on the surface of section 2 after polishing and etching the saw-cut surface. The locations of the Brinell impressions are given in Figure 4, however, the three impressions shown nearest to the front rim face were actually taken on a radial-circumferential surface of piece $2 \mathrm{~B}$, a piece that was cut from section 2 as shown in Figure 5. (Section 2 was cut into $2 A$ and $2 B$, and 2B provided a small sample suitable for metallographic and hardness studies.) Thus, the Brinell impressions taken on this piece (2B) were on a plane perpendicular to the plane shown in Figure 5. Similarly, Rockwell "C" hardness measurements were taken on the surfaces of section 2 and on piece 2B, at locations shown in Figure 6.

\section{RESULTS}

\subsection{Macroscopic Observations}

Macroscopically, the fracture surface appeared uniformly rough over the entire face except for two regions that were somewhat smoother. These regions are near the tread and near the bore, as is apparent in Figure 3. The smooth parts extend for about $3 / 4$ inches from the tread and from the bore. 
In the rim, the rough parts of the fracture show many lines with an apparent focal point on the tread near the front face of the rim, indicating that the rim fracture was the result of propagation of a crack that had initiated at the focal point. This focal point is designated by an arrow in color photographs of the rim in Figures $7(a)$ and $7(b)$.

Below the arrow there is a thermal crack which differs in appearance from that of the other parts of the heavily oxidized regions along the length of the tread. The thermal crack measures about 0.98 inches along the tread (c) and about 0.33 inches deep (a) for a c/a ratio of about 3 . This is the size and shape of the flaw believed to have existed just prior to the rapid failure of the wheel.

The appearance of a polished and etched radial-axial face of the rim (section 2) is shown as Figure 5, as etched with a hot $10 \% \mathrm{HNO}_{3}$ solution. No major defects were observed on this surface, but a heat-affected zone (HAZ) of greater than 2 inches along the tread and greater than $1 / 2$ inch in depth is observable. The HAZ has a shape similar to that of the thermal crack but the HAZ is much larger. The flow lines produced by the shaping of the wheel are visible on the etched surface. They indicate that the wheel was produced as a wrought (i.e. not cast) product.

Thermal checks are present, throughout the tread of section 2, as shown in Figure 8. The tread of section 1 also has a set of thermal checks near the fracture origin. However, the question as to whether the thermal checks actually lead up to and thereby initiated the thermal crack could not be answered unambiguously from the single fracture face available to us for this investigation.

All fillets of the wheel section were closely examined and found to be free of fatigue cracks and of any other indications of either extensive or abusive service.

\subsection{Hardness Measurements}

The results of Brinell hardness measurements, given in Figure 4, indicate that, within the wear zone of the first 1-1/2 inches of rim metal, the hardness is uniformly good, being within the range of 277 to 341 BHN specified for class $B$ wheels, except for a single value of 257 BHN for the location nearest to the front of the tread.

The values of Rockwell "C" hardness readings, as given in Figure 6, support the findings of the Brinell measurements. 
They further indicate that, near the front face of the tread, there is a large softened zone around the boundary of the heat-affected zone.

Thus, while it appears that the wheel was produced with uniformly good hardness and in accordance with the hardness specifications, the wheel has a soft zone in the region of the HAZ boundary present on the as-macroetched surface of the rim section.

\subsection{Dimensional Measurements}

The measured dimensions of the wheel, as given in Table 1, met the AAR specifications for wheels of design A-40, except for the values of $R_{1}$ and $R_{2}$. However, it is noted that the measured values of $R$, for the wheel section on which they were taken; do not represent the values of the whole wheel prior to sectioning. This is so, because the act of sectioning greatly affects these readings. It was noted by the accident investigators that the fractured wheel contained a crack with an opening of approximately 3/16 inches (presumably measured in the hoop direction of the tread). The wheel opening indicates that hoop compression, stored in the wheel prior to the fracture event, was released by the formation of the crack. The release of hoop compression would be expected to increase the value of $\mathrm{R}_{1}$ and decrease the value of $\mathrm{R}_{2}$, and our measured values for these parameters are respectively greater than and less than the specified values for the as-manufactured wheel. Therefore, all indications are that the wheel was produced in accordance with the AAR specifications on dimensions.

\section{4 Chemical Composition}

The chemical composition of the sample taken from the hub is given in Table 2. The values for carbon, manganese, phosphorous, sulfur, and silicon, indicate that the steel met the chemical compositional requirements of the AAR Specification M-170-69. In addition, the values given for nickel, chromium, molybdenum, and copper, indicate that the steel is a carbon steel grade with small amounts of these alloy additions, and that the contents of these alloy additions are insufficient to make the steel a low-alloy grade.

\subsection{Metallographic Examinations}

Careful metallographic examinations and measurements of the maximum depth of the heat-affected zone (HAZ) on piece 2B from section 2 indicate that the maximum HAZ depth on piece 2 
is about 9/16 inches. This measurement, coupled with measurements made on the macroetched surface, indicate that the HAZ extends along the tread for a distance of about 2 inches from the front face of the rim.

The microstructures of the unaffected base metal, of the fine-grained region near the inside boundary of the HAZ, and of the coarse-grained HAZ region near the focal point of the thermal crack are each shown at two magnifications in Figures 9, 10, and 11, respectively. These microstructures were observed on piece $2 \mathrm{~B}$ at the locations designated C, B, and $A$, respectively, in Figure 5 .

We note that transformation to the structure shown in Figure 11 (region A) requires temperatures estimated to be as high as $1850 \mathrm{~F}$. The structure shown in Figure 10 (region B) requires about $1400 \mathrm{~F}$. Thus, the magnitude of the heat input locally, at the front part of the tread, was large.

\subsection{Fractographic Examinations}

In general, the SEM replicas indicated that the failure occurred by a quasi-cleavage failure mode over the bulk of the surface of the fracture. The results of observations of the fracture surface near the focal point of the thermal crack were somewhat indeterminate, but they are consistent with the idea that the failure was preceded by the formation of a thermal crack that was initiated at this site.

The appearances of replicas taken from locations C, D, A, and L (Figure 3), were similar, with each showing fracture by a predominantly quasi-cleavage mode, as is shown in Figures 12 through 14. Figures 12 and 13 are considered to be representative of the overall failure mode. Figure 12 shows fractographs taken in location $\mathrm{C}$, the geometric center of the rim section. Figure 13 is a stereo-pair fractograph taken at area $\mathrm{L}$, in a lower part of the rim. The fracture surface at D, the back-rim plate fillet, was similar to those shown here. Figure 14 taken in location A near the boundary of the heat-affected zone near (or just within) the thermal crack shows quasi-cleavage failure with. some oxides also being present on the surface.

The fracture mode could not be clearly established for location $A$, near the focal point of the thermal crack, and for location $M$, from the hub. The replicas taken from these locations indicated the fracture face to be either highly oxidized, or badly rubbed after the fracture event. This is shown in Figures $15 \mathrm{a}$ and $15 \mathrm{~b}$, respectively taken from 
locations $A$ and $M$. The parts of these surfaces that do seem to represent actual fracture surface may even have been disturbed by oxidation or abrasion. Nevertheless these parts are very smooth in appearance, similar to a cleavage failure mode.

\section{DISCUSSION}

Measurements of hardness, chemical composition, and dimensions taken on the wheel section submitted to NBS indicate that the wheel met the AAR Specification M-107-69, for wrought, carbon steel wheels, and the requirements for Class $B$, rimtreated wheels of design A-40.

On the face of the fracture, a thermal crack was observed. This crack has a focal point on the tread near the front face of the rim. Further, it is encompassed by a heat-affected zone (HAZ) that is larger than the apparent size of the thermal crack. Thus, the thermal crack and the HAZ that surrounds it are believed to have resulted from substantial local heating of the front part of the tread.

The results of hardness measurements indicate that the wear metal of the rim was of uniform good hardness except for the region around the boundary of the HAZ. Thus, it is believed that the rim was properly heat treated in production and that the observed soft parts are the result of service overheating of the tread. near the front face of the rim. This overheating is believed to have led to the formation of the thermal crack and, in turn, to the crack that propagated through the wheel causing it to fail functionally. This later event of propagation is believed to have occurred very rapidly. Thus, the rapid failure of the wheel is believed to have resulted from a thermal crack formed by overheating of the tread in service.

The fractographic examinations indicate that: (1) the wheel failed by a brittle failure mode referred to as quasi cleavage and (2) the region of the thermal crack could have existed before the failure of the wheel.

\section{RECOMMENDATIONS}

For future studies of wheel failures it is recommended that an entire failed wheel should be submitted along with a companion wheel of the same production and service history as the failed wheel. The material's structure and properties, 
along with the residual stresses of the wheel are combined to give the wheel its protection against service failure. Thus, it is believed that, with a failed wheel and a similar unfailed wheel, further information can be developed on both the mechanical properties of the material and the stresses within the wheel, as they relate to questions of fracture and of the overall suitability of the wheel for a service application. In any event, whether or not a comparison wheel is sent, the entire failed wheel should be sent for failure analysis whenever this is feasible. 
Table 1

Comparison of the Dimensions Specified by AAR and the Measured Values Taken from the Failed Wheel

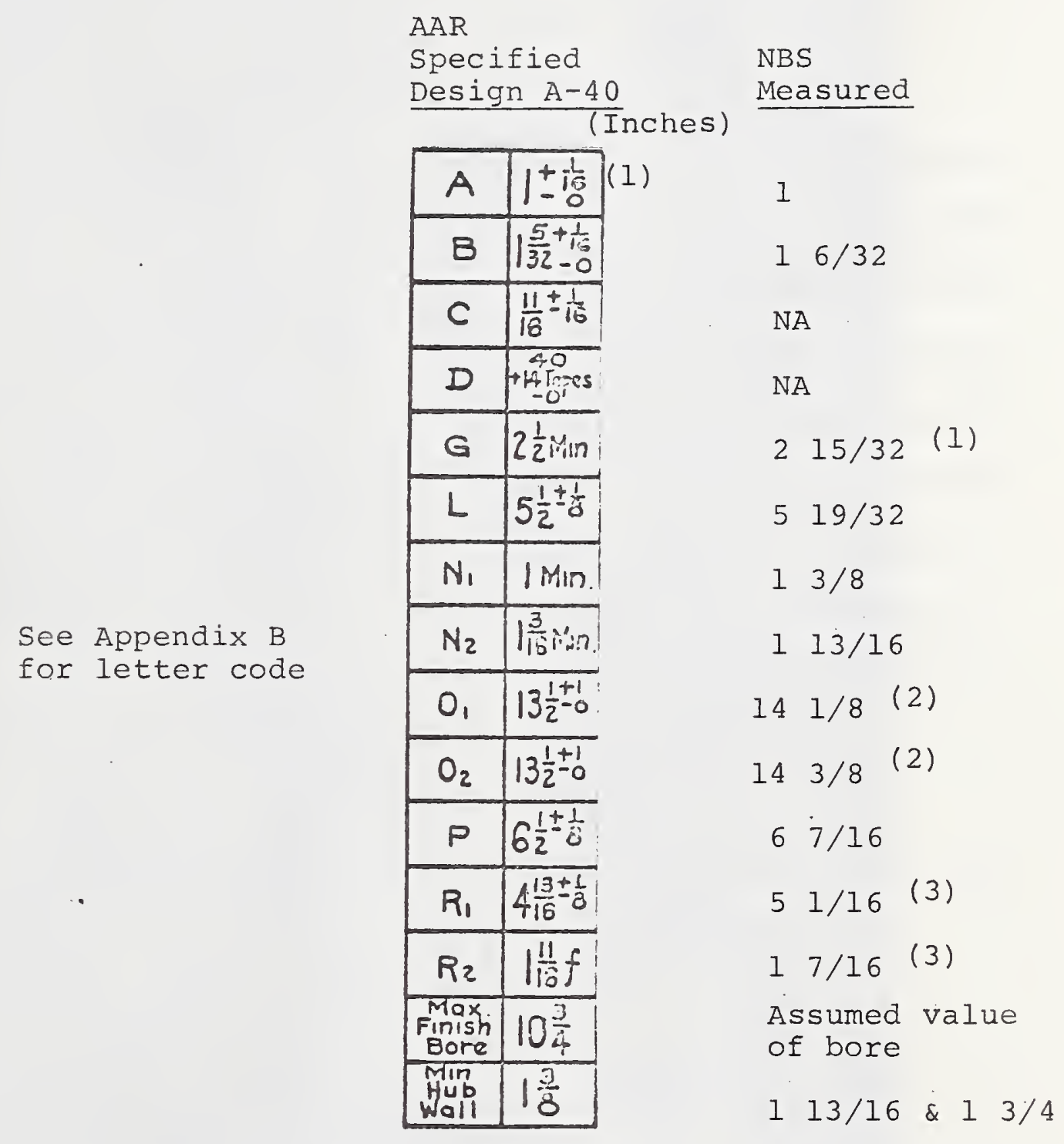

(1) Attributed to normal service wear.

(2) These measurements are calculated from the assumed bore value of $103 / 4$ inches and the value of the measured hub thickness.

(3) The values of $R_{1}$ and $R_{2}$ were affected by the release of residual stress during the fracture event and during subsequent sectioning of the wheel. Thus the measured values given here do not represent the values for the wheel in service. 
Table 2

Chemical Composition of the Sample Taken

from the Hub. (Percent by Weight)

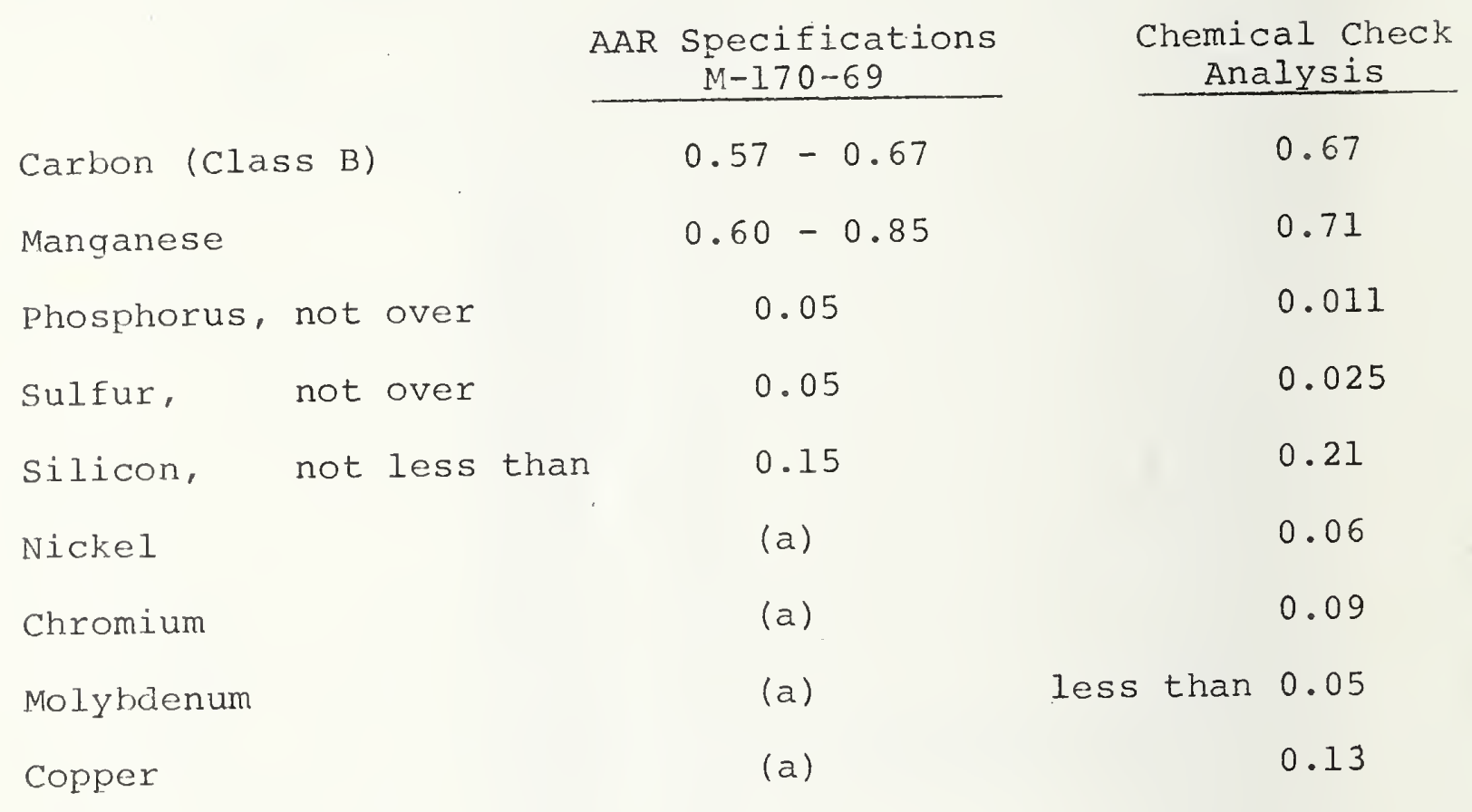

(a) Not specified. 


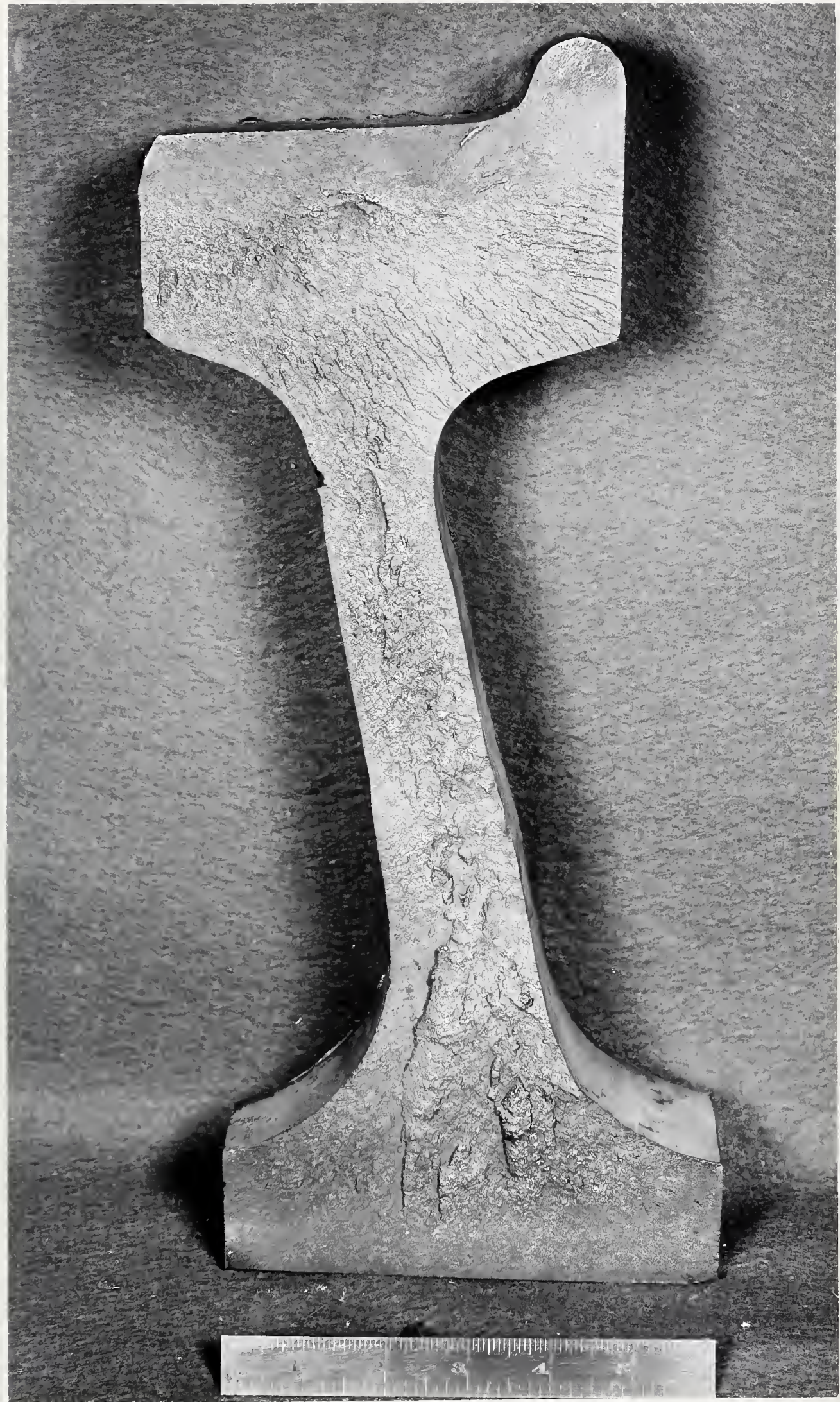

Figure 1. Radial-Circumferential section of the Fractured Wheel, As Received at NBS. Mag. X $1 / 2$ 
Figure 2. Fractured wheel Section Showing the Three Parts Into Which It Was Saw Cut.

Section 1 was used for macroscopic and microscopic examinations of the fracture. Section 2 was used for hardness and heat-affected zone measurements, macroscopic and microscopic examination; and Section 3 was used for chemical analyses. Mag. $<\mathrm{X} 1 / 2$ 


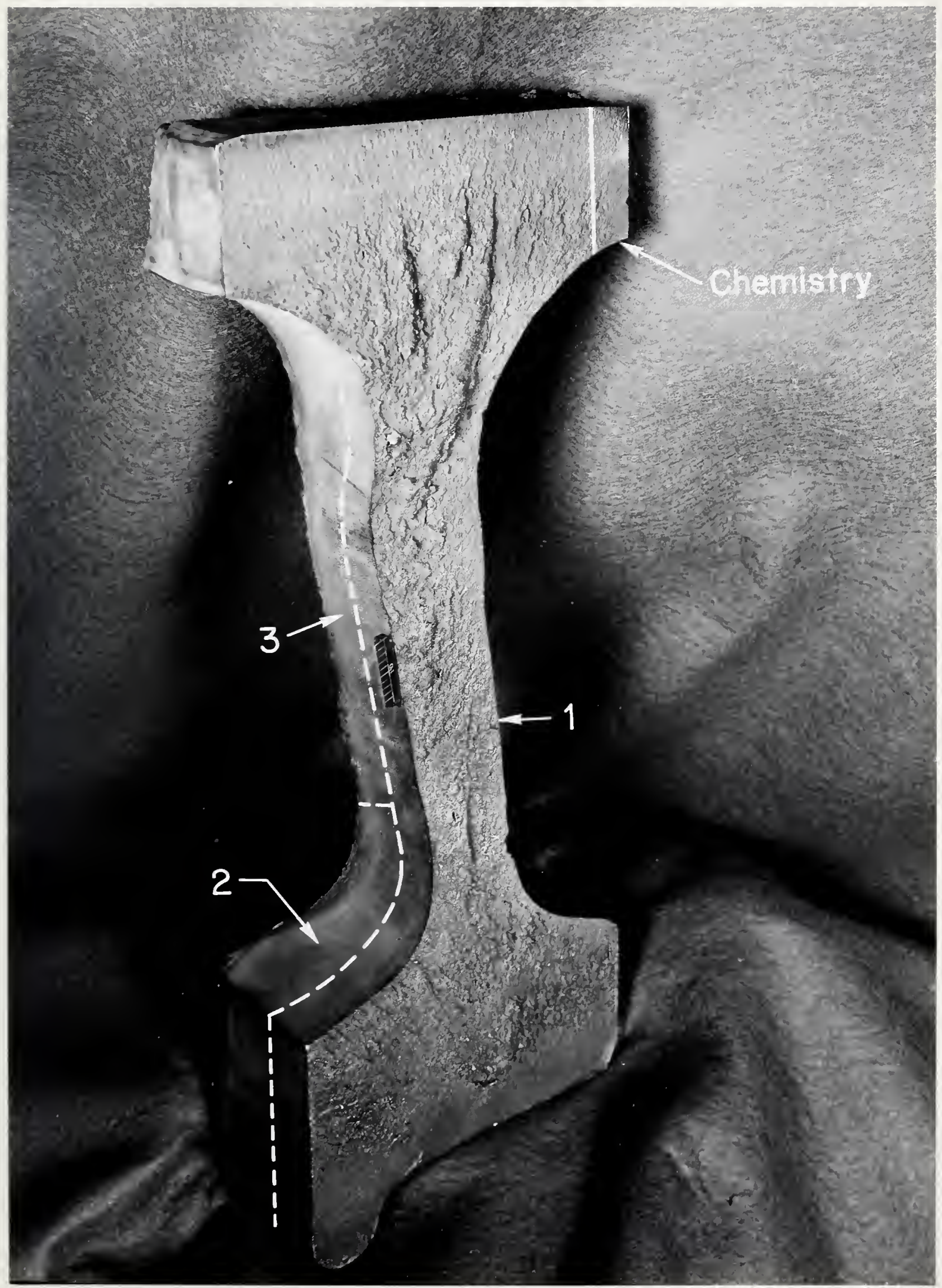






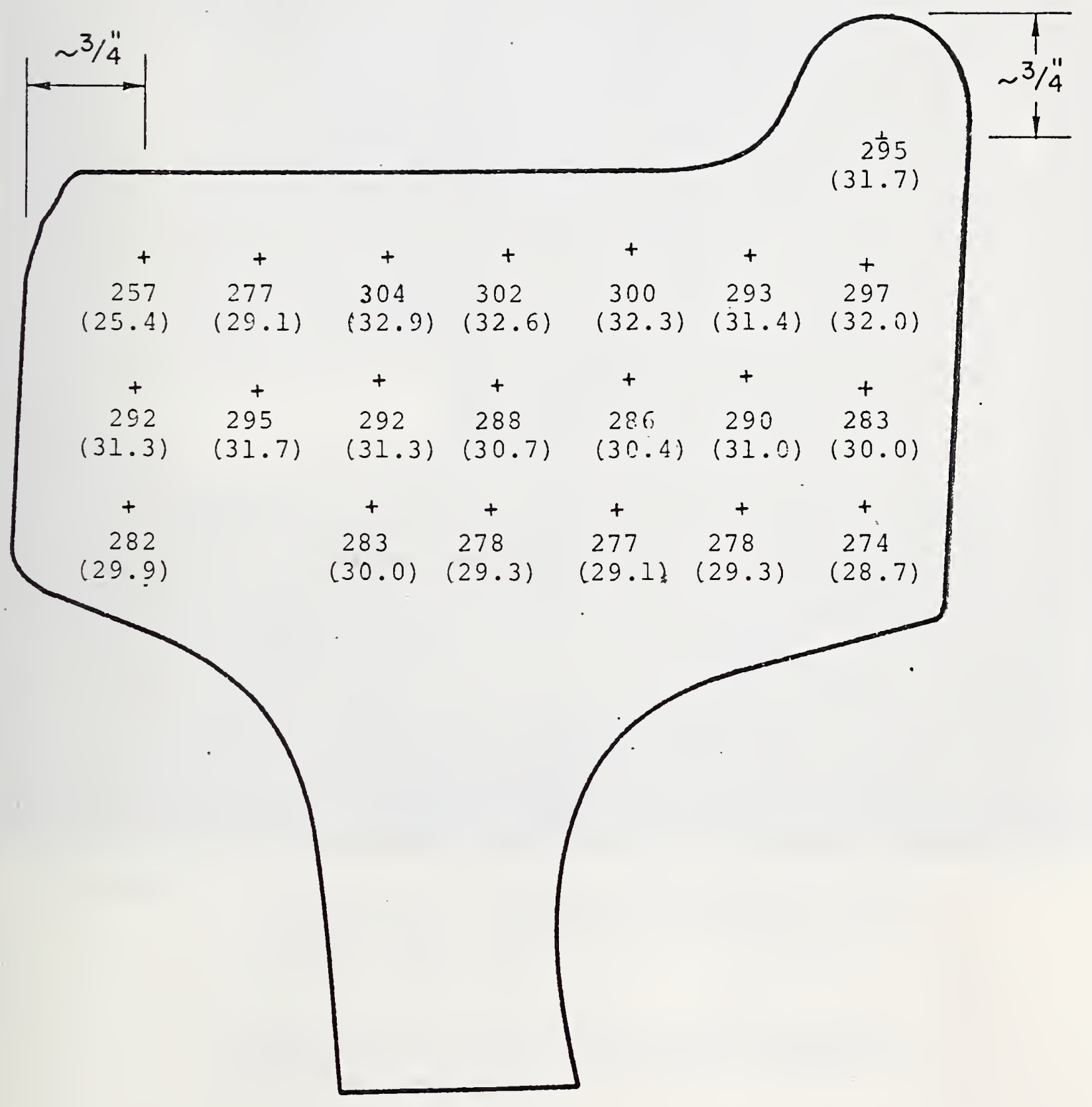

11/41, 4. Sichomatic Reprusentation of the Location of Brinell Hardness Impressions and l:quivalent Rockwell C values (in pirenthesis). Mag. X 1 



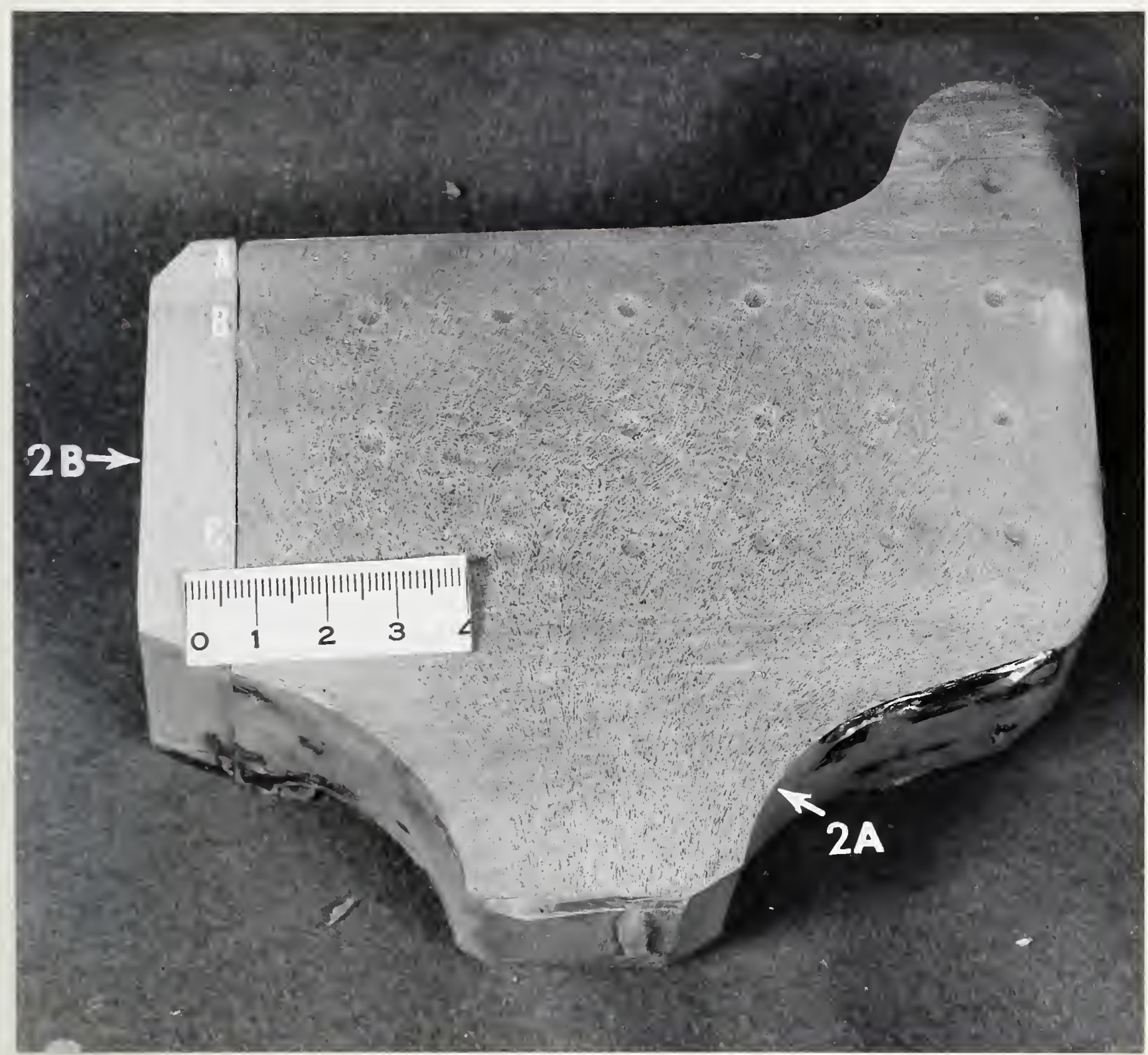

Figure 5. Photograph of Section 2 Showing the Brinell and Rockwell C Hardness Impressions, the Etched Sample, and the Saw Cut Between Pieces $2 \mathrm{~A}$ and $2 \mathrm{~B}$.

Regions A, B, and C were used for photomicrographs of the structures observed in the rim. Mag. $x 1$ 



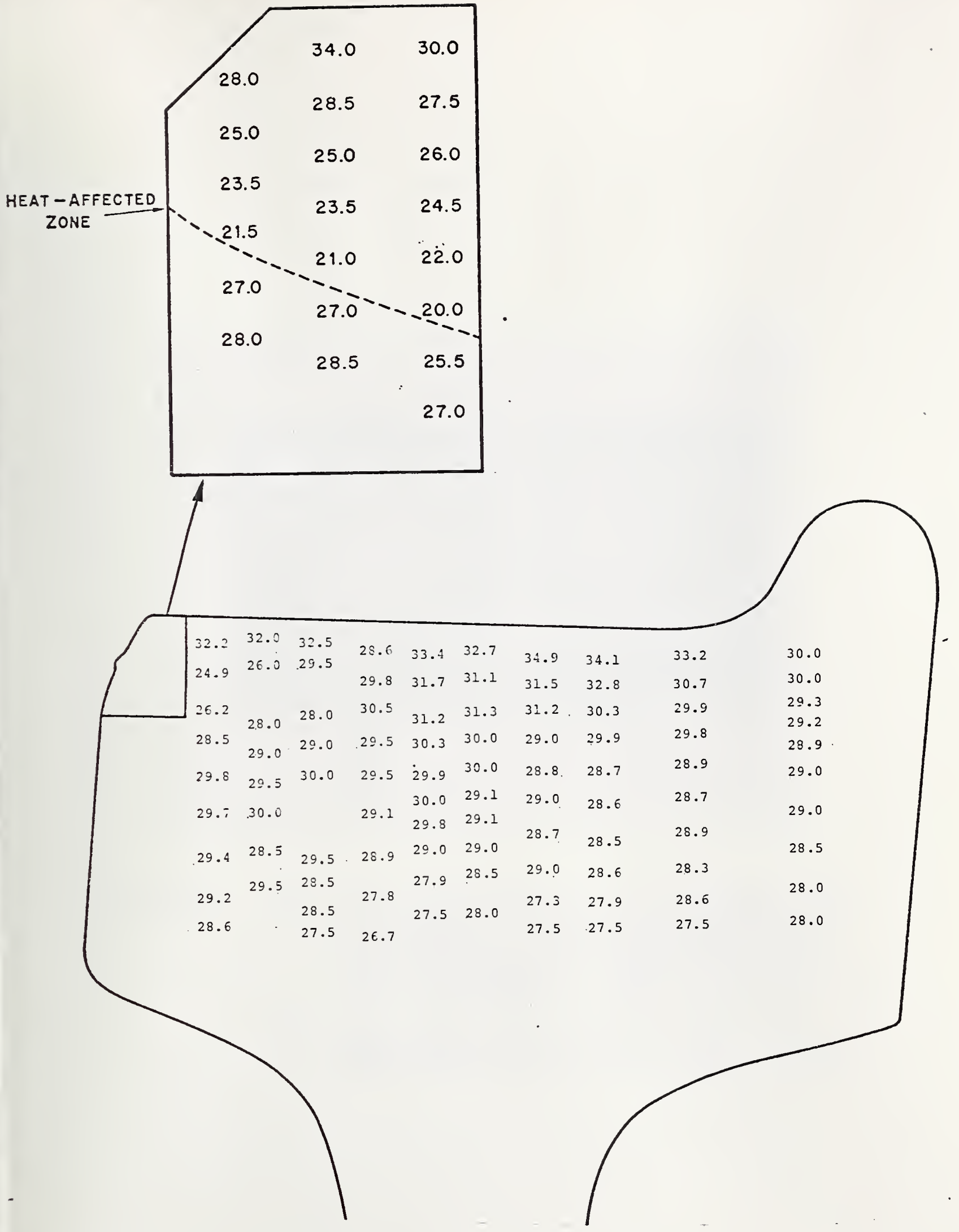

Figure 6. Results of Rockwell "C" Hardness Measurements Taken on Section No. 2 . Locations of $\mathrm{R}$ impressions correspond to locations of decimal points shown here. 



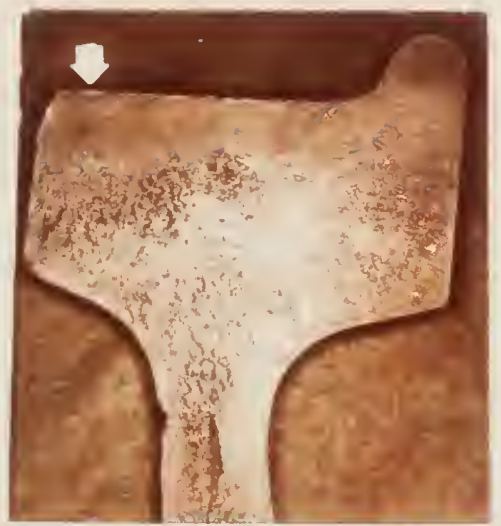

(a)

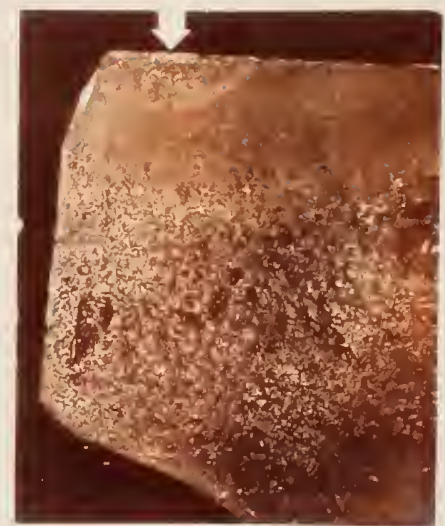

(b)

Figure 7.

(a) Color Photograph of the Fracture Face of the Rim, Showing the Location of the Thermal Crack (Initiation Site) and the Oxidized Region Near the Tread and in the Flange. Mag. $\sim \mathrm{X} 1 / 3$

(b) Close Up of the Thermal Crack Near the Front Face of the Rim. Mag. X 2/3 



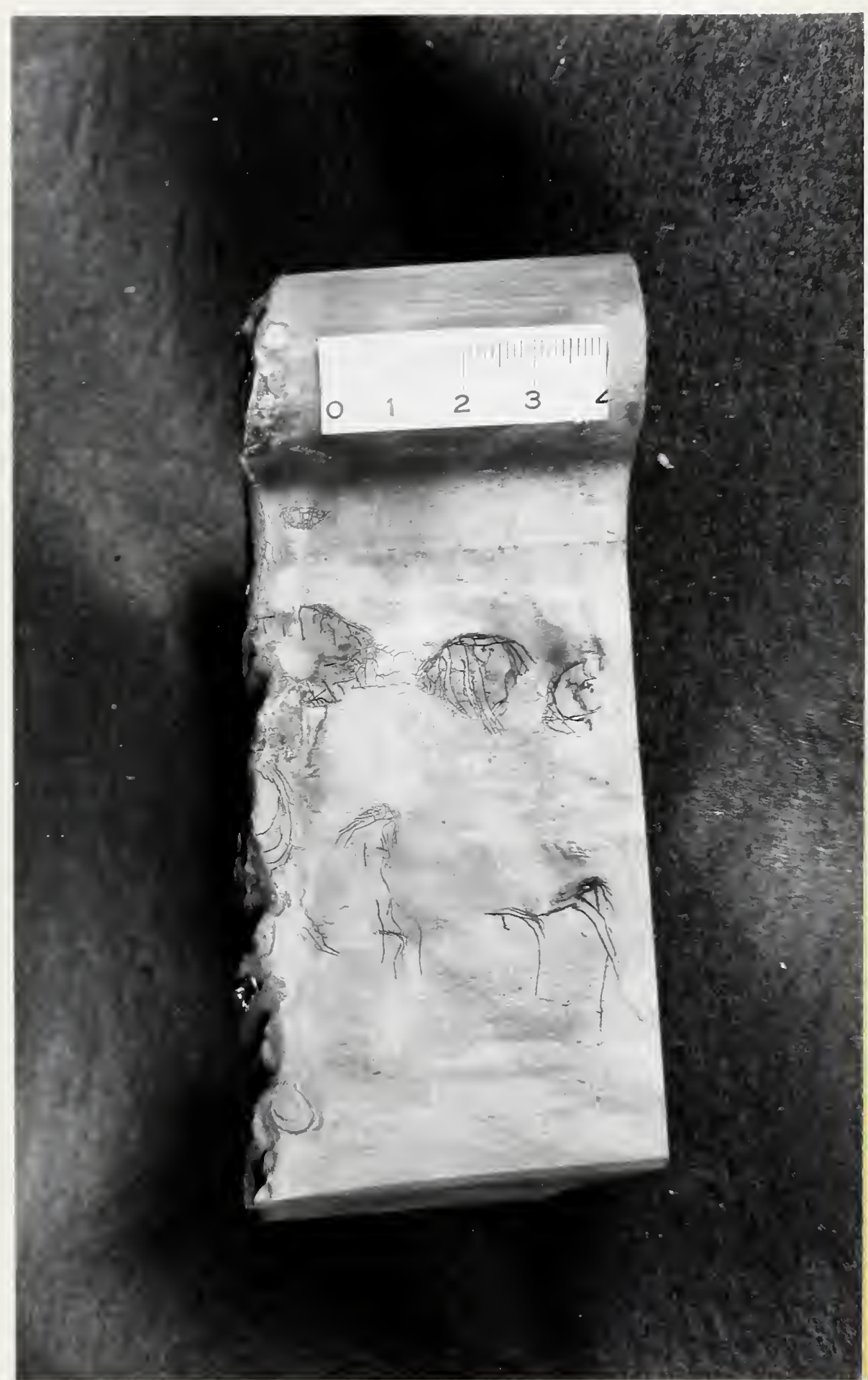

Figure 8. Thermal Checks Observed on the Tread of Section 2 After Hot Etching in 1:1 HCl. Mag. $\sim \mathrm{X} 1$ 



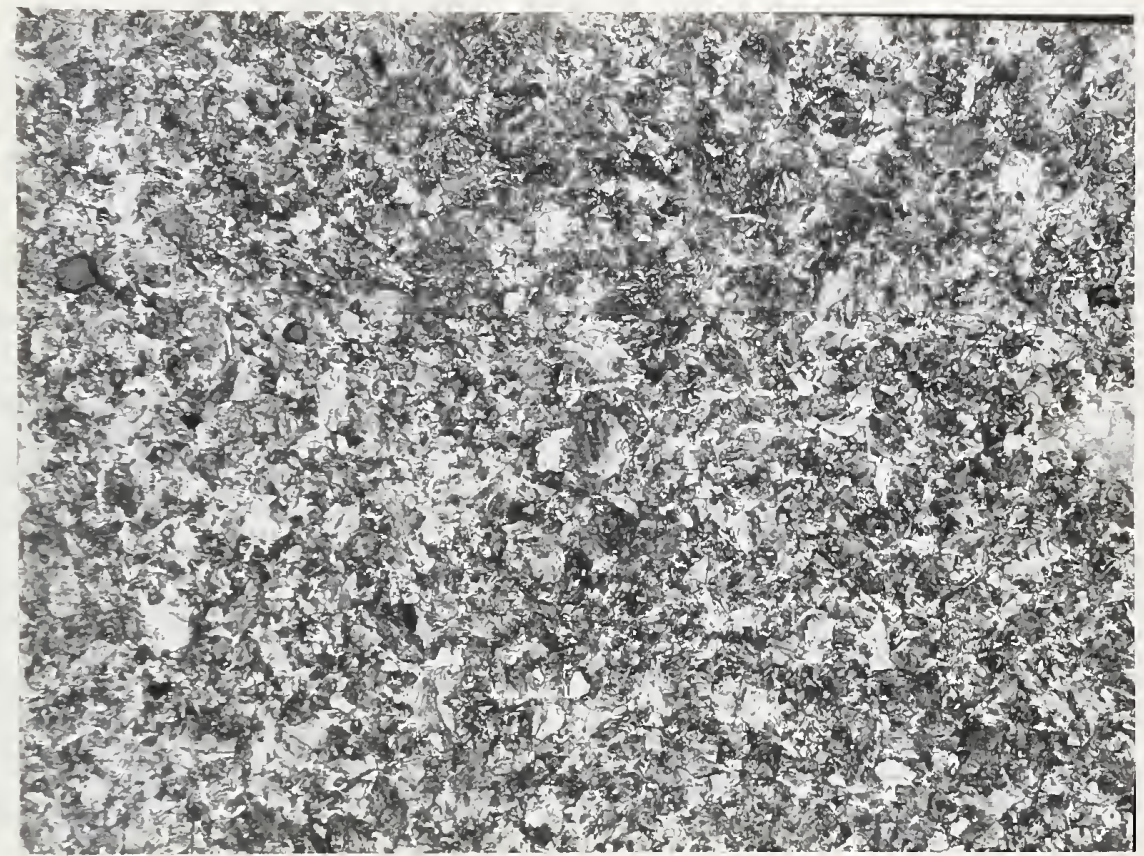

Mag.

$\mathrm{X} 100$

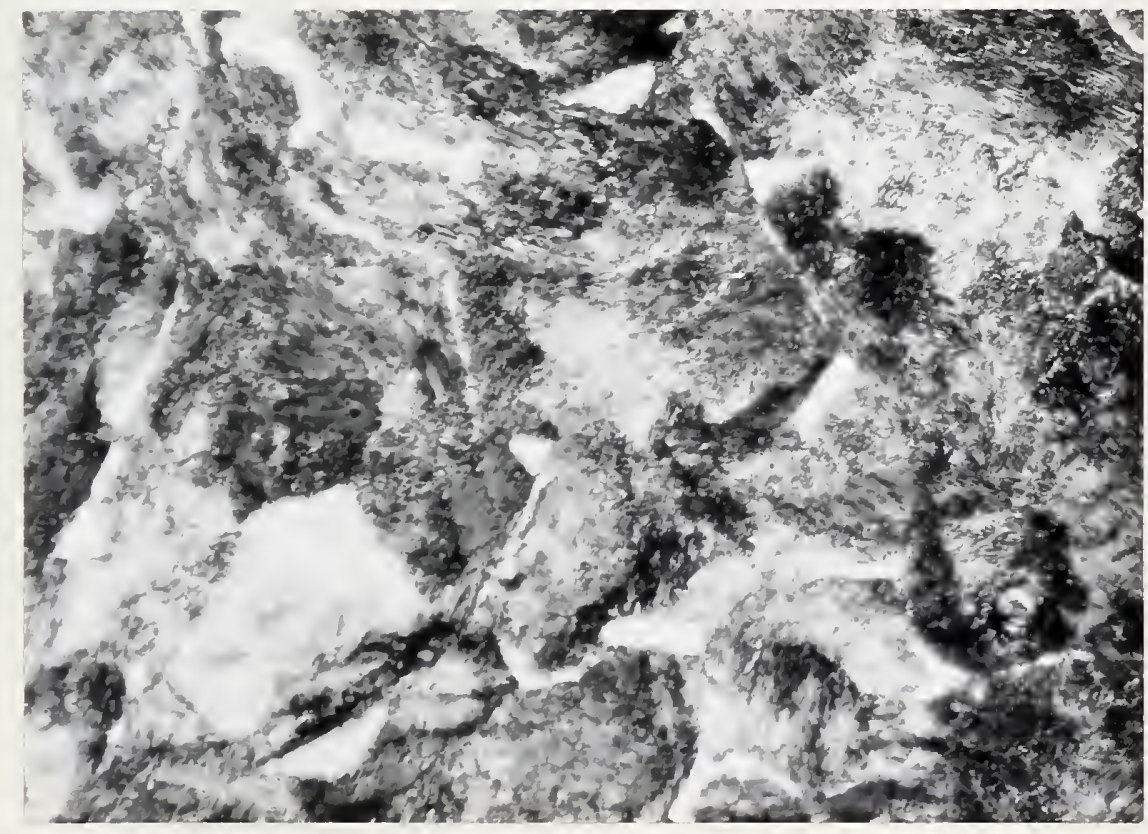

Mag.

$\mathrm{X} 1000$

Figure 9. Photomicrographs Taken at Region C (Figure 5) Showing the Unaffected Base Metal of the Rim.

Specimen etched with 5\% nital. 



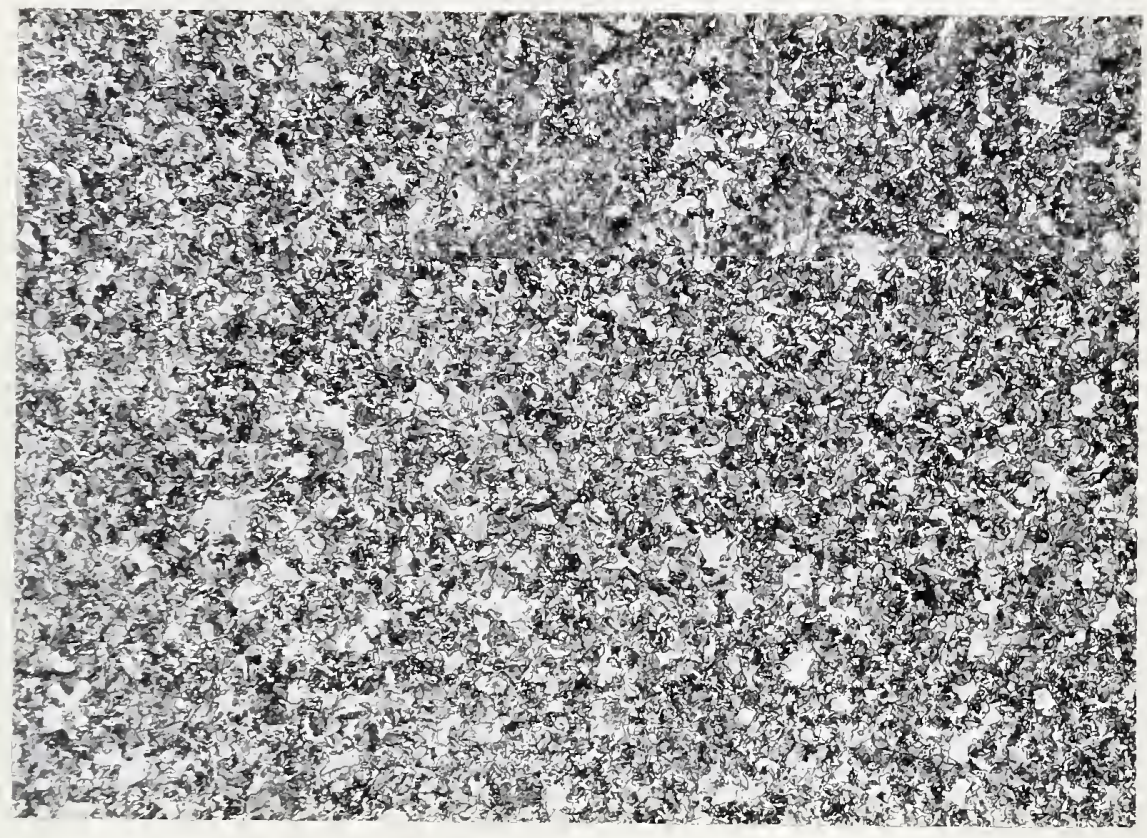

Mag .

$\mathrm{X} 100$

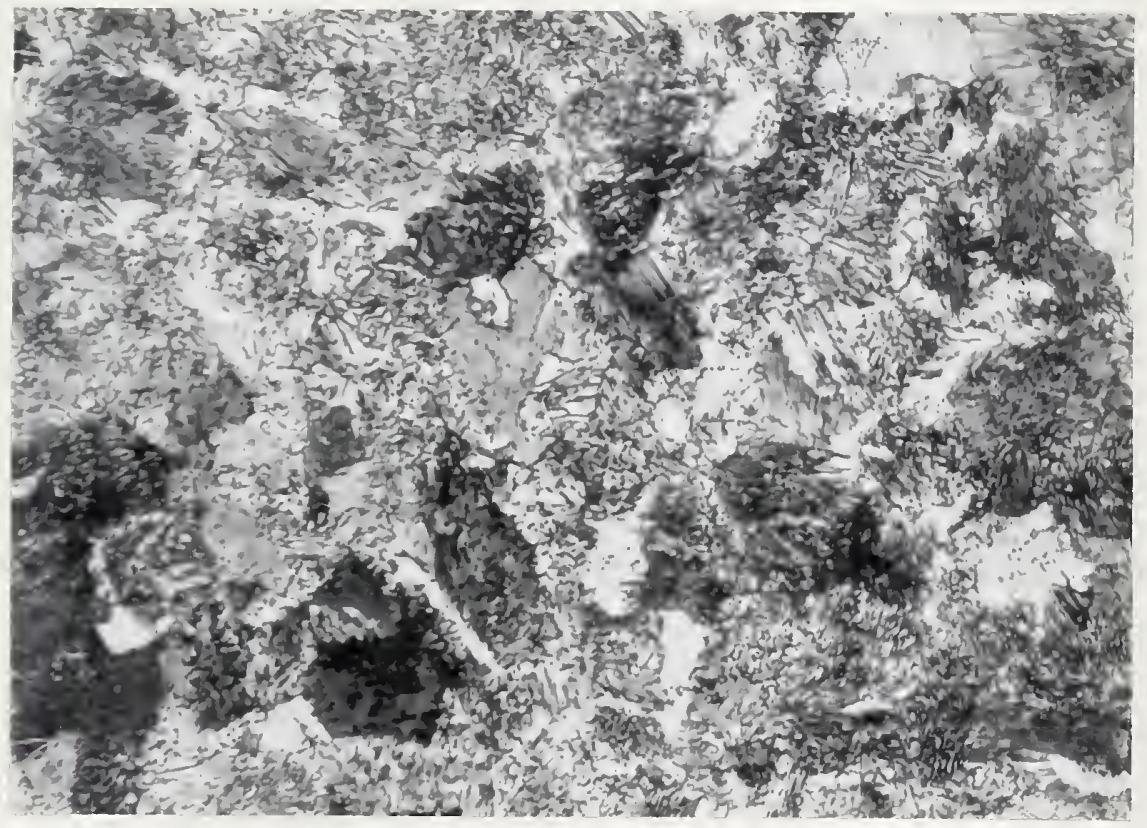

Mag .

$\times 1000$

Figure 10. Photomicrographs Taken at Region B (Figure 5) Near the Inside of the HAZ Boundary.

Specimen etched with 5\% nital. 



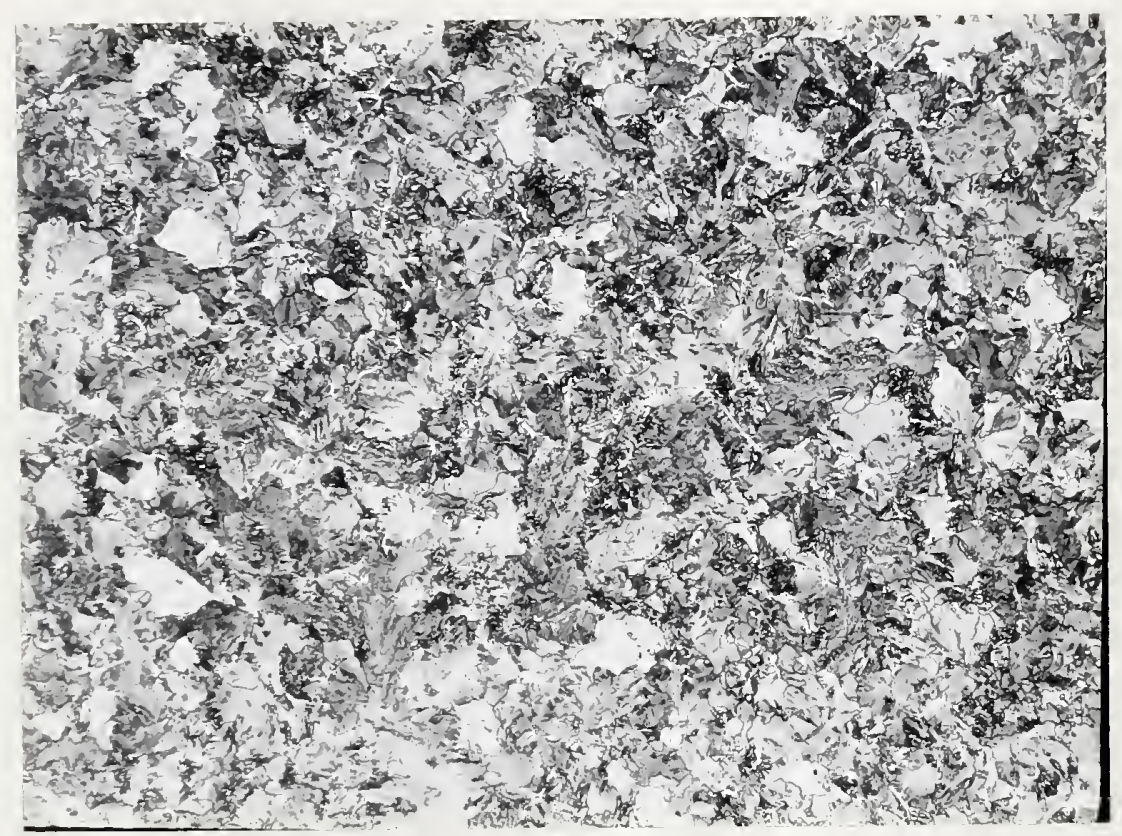

Mag .

X 100

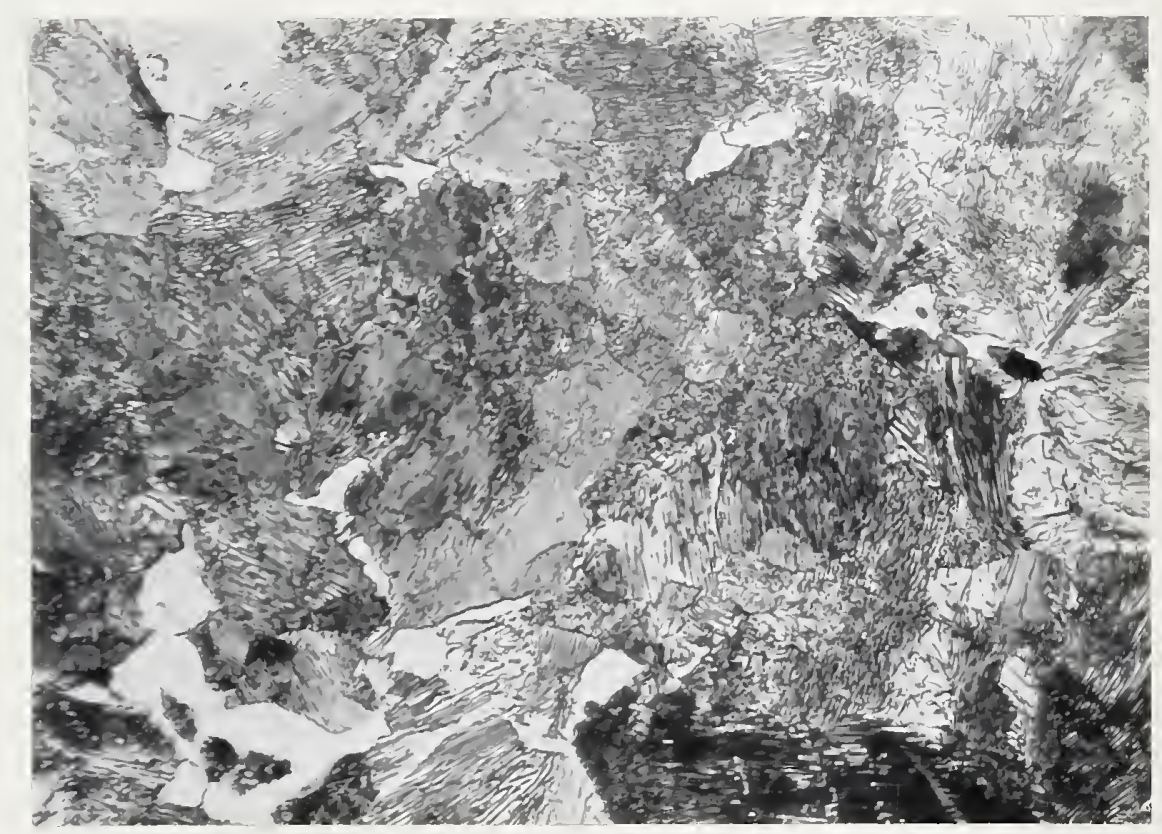

Mag.

$\mathrm{X} 1000$

Figure 11. Photomicrographs Taken at Region A

(Figure 5) Showing the Coarse-Grained Heat-Affected Zone Observed Near the Tread.

Specimen etched with 5\% nital. 



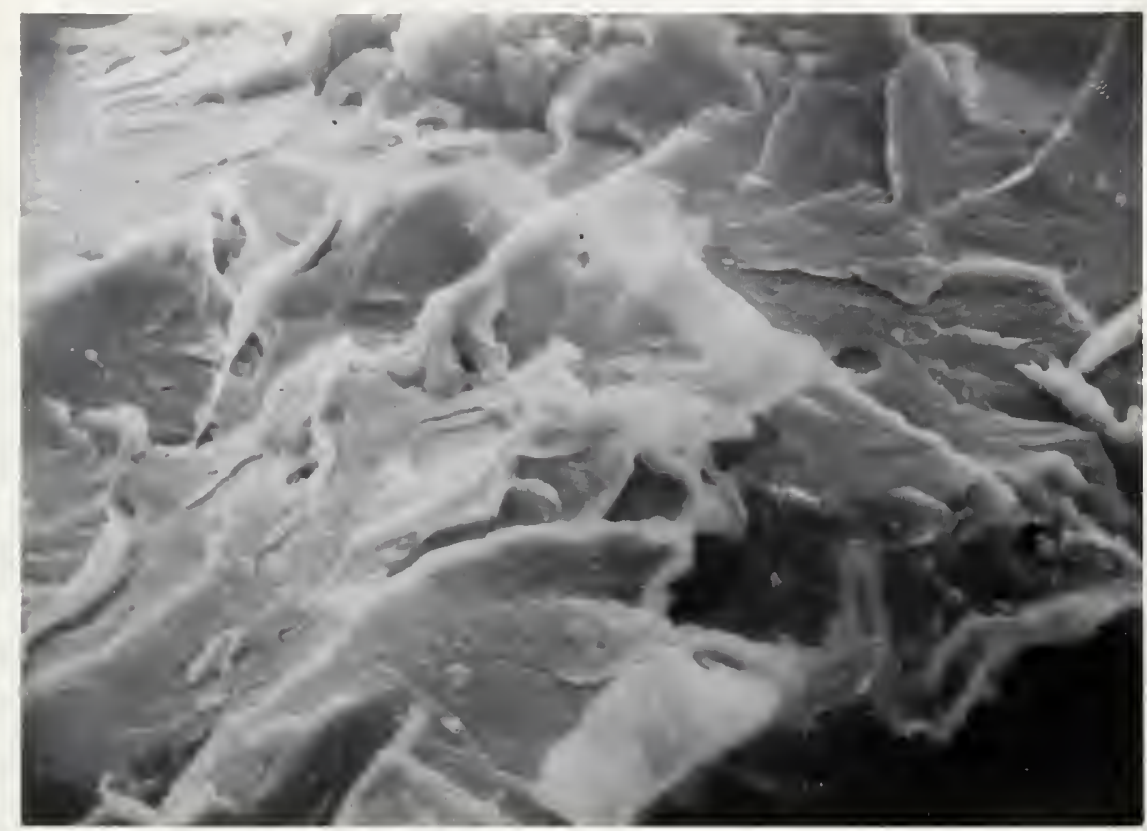

Mag.

$\times 1050$

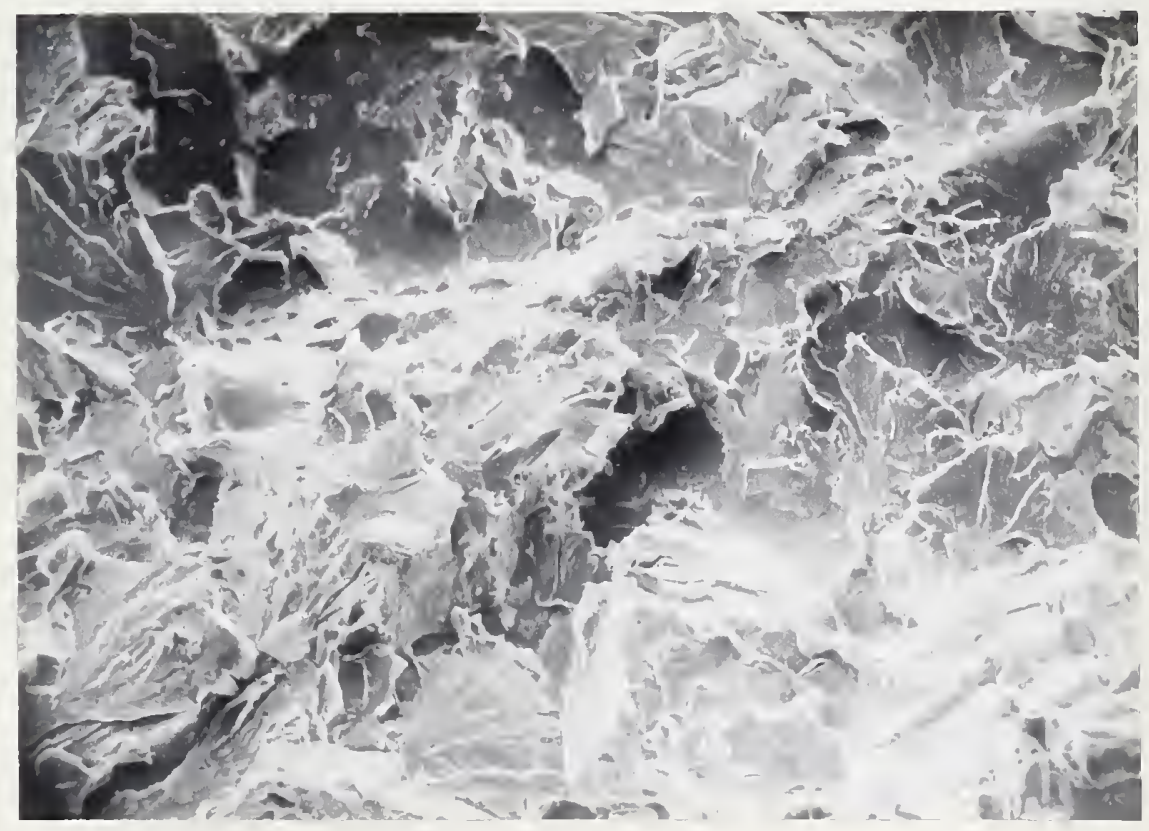

$\underset{\mathrm{M}}{\mathrm{Mag}} \mathrm{i}$

Figure 12. SEM Fractographs Taken at Location $C$ of Figure 3, Showing the Predominately Quasi-Cleavage Fracture Mode Observed in the Rim. 



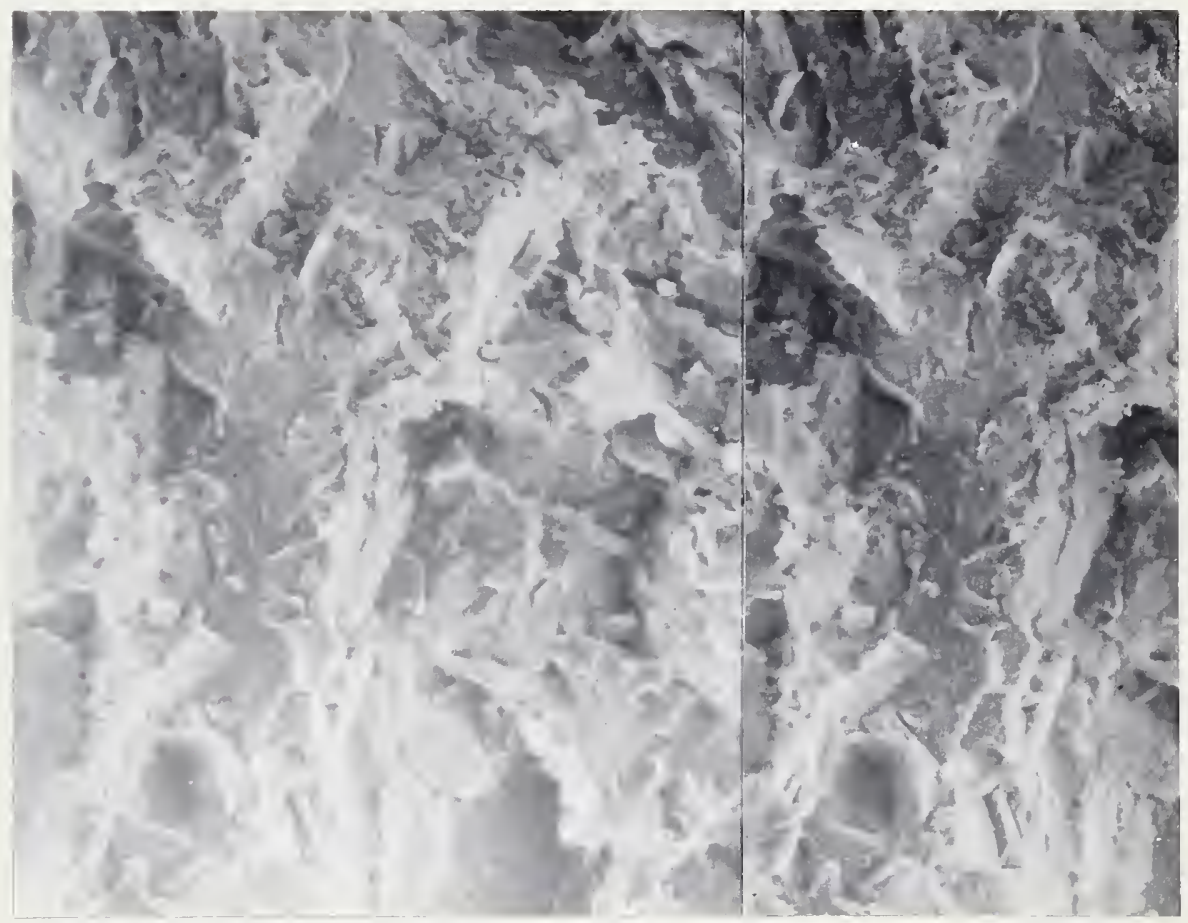

Figure 13. SEM Stereo-Pair Fractograph Taken at Location I of Figure 3, Showing the Predominately Quasi-Cleavage Fracture Mode Observed in the Rim. Mag. X 490 



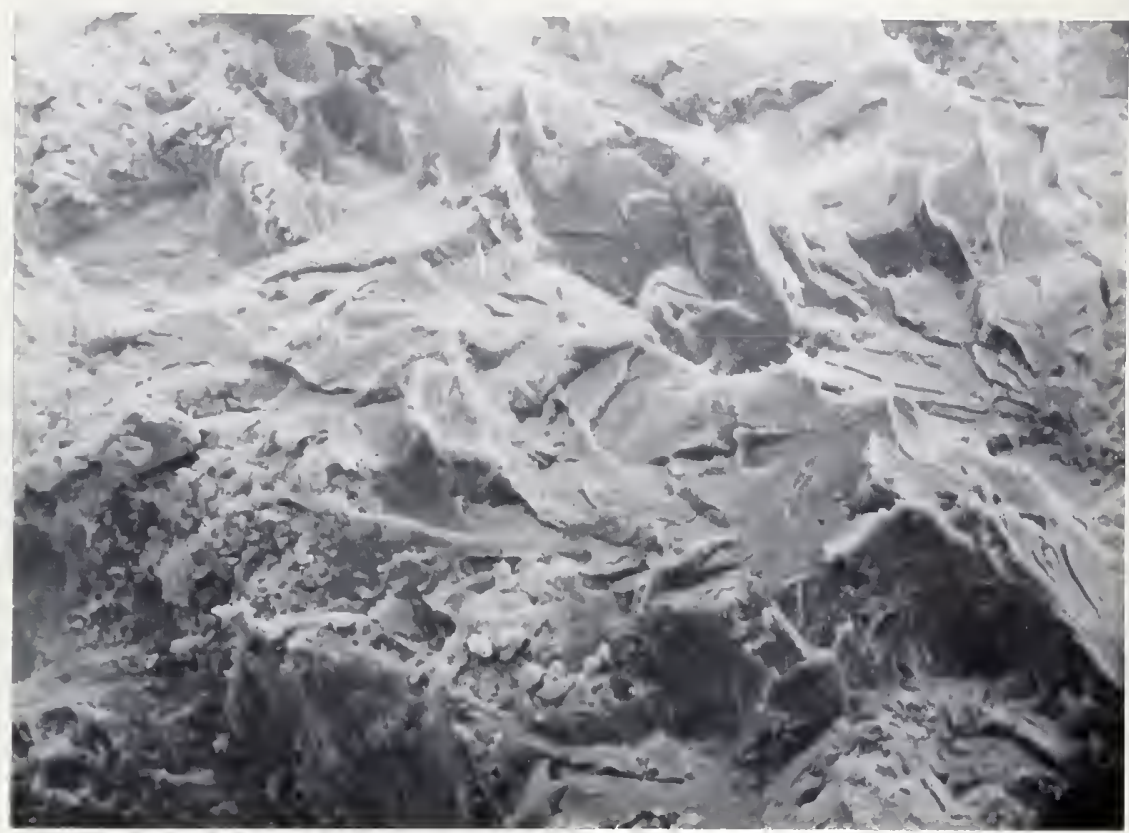

$\stackrel{\mathrm{Mag}}{\mathrm{x}} 30$

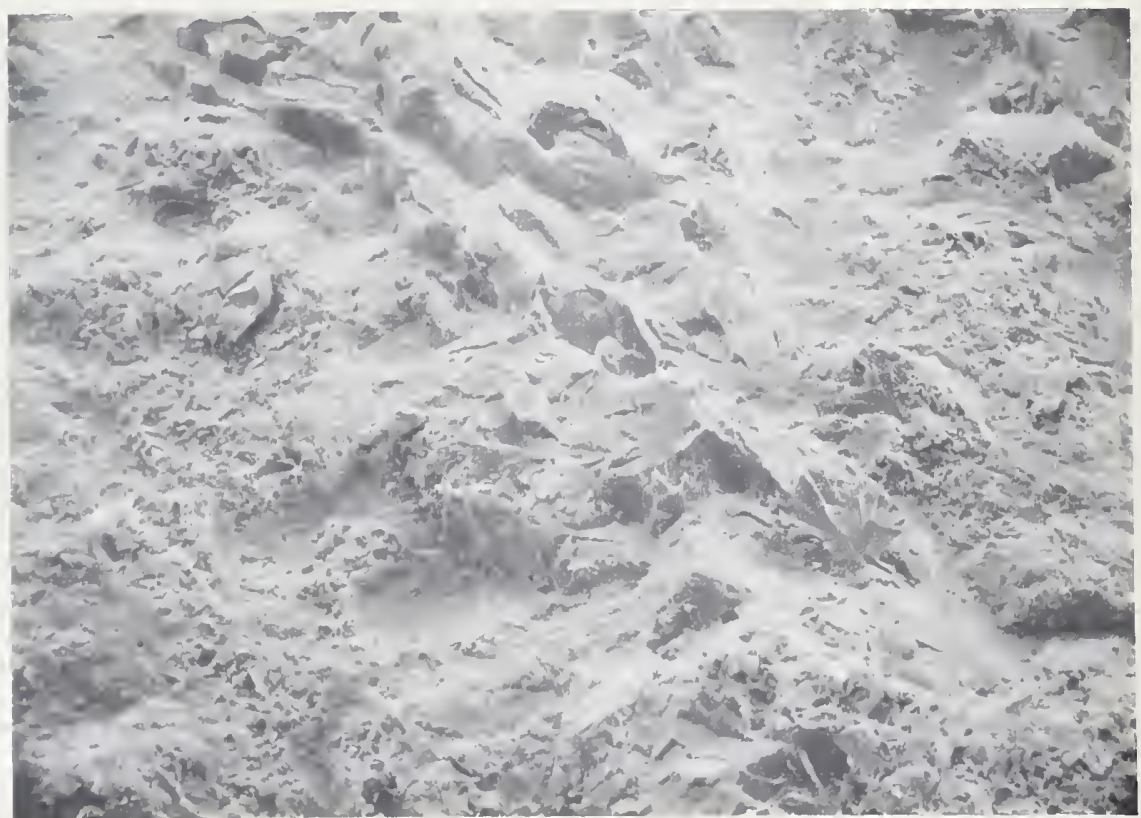

$\underset{\mathrm{M}}{\mathrm{Mag}} \mathbf{1 5 0}$

Figure 14. SEM Fractographs Taken at Location A of Figure 3, Showing Quasi-Cleavage Fracture and Oxide Formations Observed Near the Boundary of the Heat-Affected Zone of the Rim. 



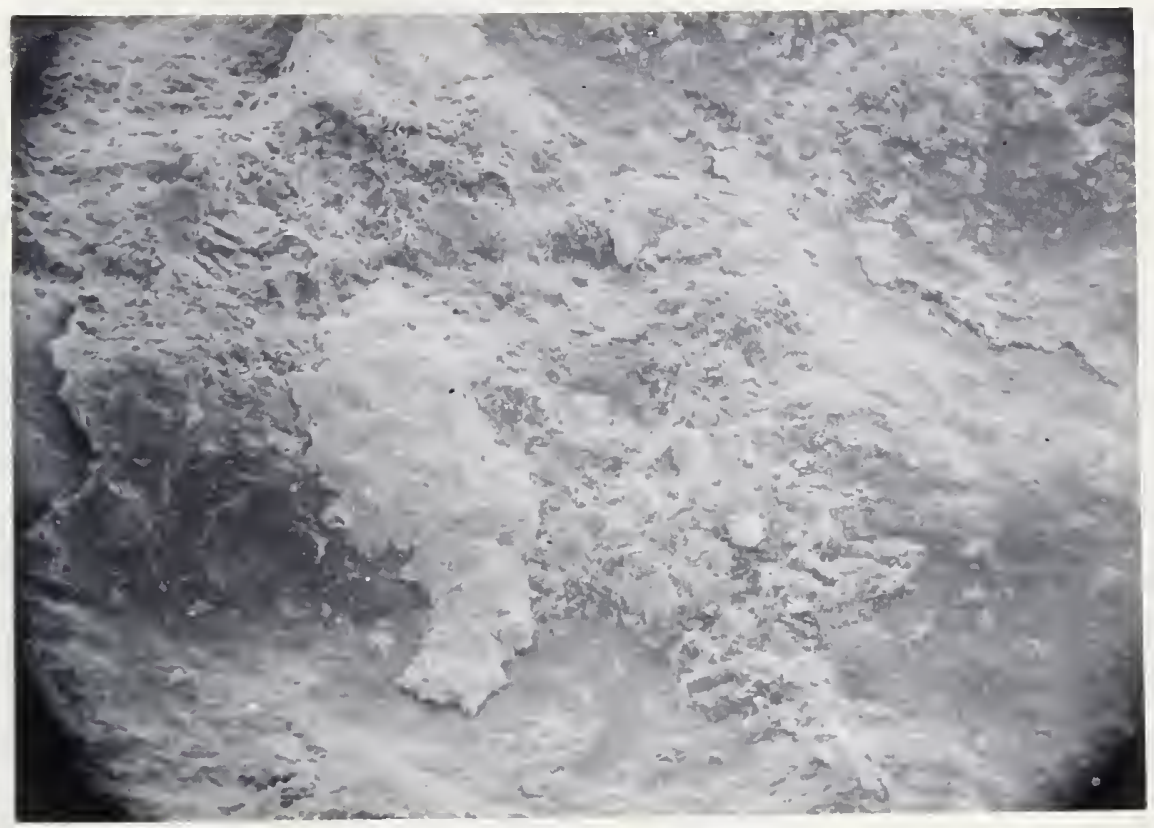

Mag. X 160

Location A

in Figure 3

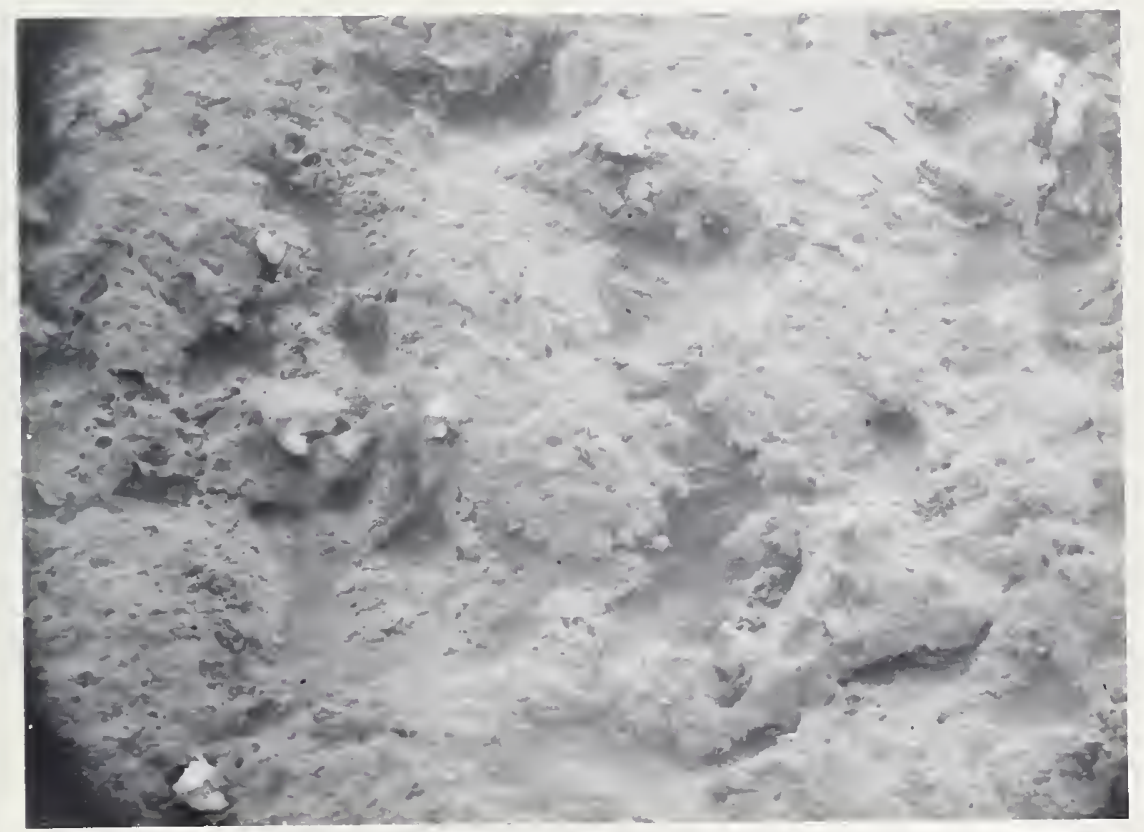

Mag. X 100

Location $M$

in Figure 3

Figure 15. SEM Fractographs Taken from the Thermal Crack Region (15a) and from the Hub Region (15b), Showing Oxide Formations, Abraided Parts, and Flat Fracture. 

APPENDICES 
APPENDIX A

(Specification)

AAR-M-107-69 


\title{
ASSOCIATION OF AMERICAN RAILROADS \\ OPERATIONS AND MAINTENAYCE DEPARTMENT MECHANICAL DIVISION
}

\author{
SPECIFICATIONS \\ $\mathrm{M}-107-69$
}

\section{WHEELS, WROUGHT CARBON STEEL}

Adopted, 1962, to Supersede Previocs Stavdard Specific.tTons For

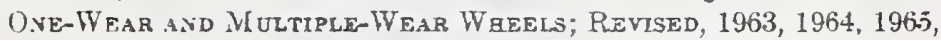
$1966,1967,1969$

1. Scope.-(a) These specifications cover one-wear, two-wear and multipie-wear wrought carbon steel wiheels for locomotives and cars-Class U, uncreated, and classes A, B and C beat treated wheels.

(b) The service for which the rarious classes are intended generally is as follows:

Clasy U - General service where an untreated wheel is satisfactory.

Class A - High speed service with severe braking conditions, but with moderate wheel loads.

Cliss B - High speed service with severe brabing conditions and heavier wheel losds.

$\mathrm{Clidy} \mathrm{C}-(1)$ Service with light oraking conditions and high wheel loads.

(2) Service with heavier braking conditions where off-iread brakes are employed.

2. Design.- Standard and temporary standard designs and tread and fiange contours for wrought steel wheels shail be as shown in Section G Wheels in the A.A.R. Manual of Standards and Recommended Practices. Application for approval of designs not shown in Section $\mathrm{G}$ shall be addressed to the Secretary of the Mechanical Divivion, A.A.R, for submission to the Committee on Wheels and Axles.

\section{Makr}

3. . Process. The steel shall be made by any of the following processes: Oper bearth, electric furnace, or basic oxygen process."

*. Basic-oxygen proces is defined as the steelmaking process in which molten iron is refined to steel under a basic slag in a cylindrical furnace lined with basic refractories, by directing a jet of high-purity gaseous oxygen onto the surfars of the bot metal bath.

4. Discard.-A sufficient discard shall be made from each ingot to insure freedom from piping and undue segregation.

5. Temperatures.-During the manuacture, necessary care in the regulation of temperature gradients shall be exercised to obtain the physical pronerties to be expected from the chemical composition and mechanical work and to provent the derolopment of iaulty structure." All wheels immediateiy af ter the last hot fabricating operation (coning or dishing), shall be allowed to cool to a temperature belor the critical range. The cooling shall be coatrolled to prevent injury by 200 mpid cooling below the critical range

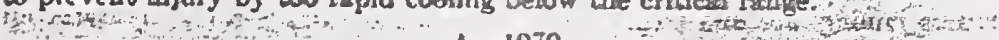


6. Heat Treatront-(a) For clases A, B and C whels, the heat treatment shall consist of trestment of either the rim only or of the entire wherl, unless purchaser's order indicates preference.

(b) Rim Quenching Treatmeat. - The wheels shall be uniformily rehested to the proper temperature to refine the grain and then the rims shall be quencbed. Following quenching, the wheels shall be charged into a furnace for tempering to meet the requirements of Section $\dot{s}$, sad subsequently cooled under controlled conditions.

(c) Entire Wheel Quenching Treatment.-The wheels shall be uniformly rebeated to the proper temperature to refine the grain and then shall be totally immersed in a quenching medium. Following quenching, the wheels shall be charged into a furnace for tempering to meet the requirements of Section 9, and subsequently cooled under controlled conditions.

\section{Chrichich Repumearems}

7. Ladle Analysis, - (s) The steel shall conform to the following chemical requirements:

Per Cent

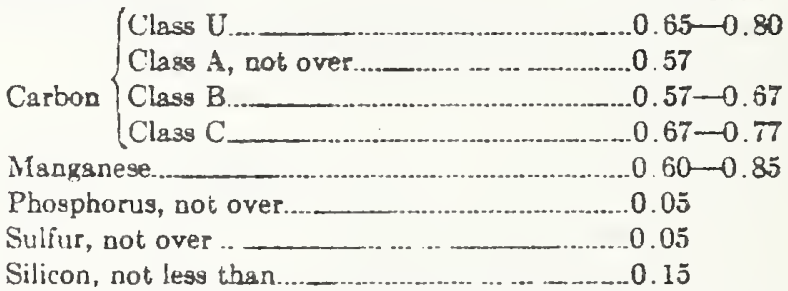

(b) An analysis of each beat of steel shall be made by the manufacturer to determine the percentage of the elements specified in Section 7. This analysis shall be made on a test specimen taken during the pouring of the beat. The chemical composition thus determined, together with such identifying records as may be desired, shall he reported to the purchaser or bis representative, and shall coninrm to the requirements specifed in Section 7.

8. Check Analysis. - An analysis may be made by the purchazer from a wheel block or from a finished wheel selected from each heat by the purchaser's representative. The chemical composition thus determined shall conform to the requirements specified in Section 7 , with a permissible carbon variation of minus 0.02 or plus 0.03 pereentage points. Samples from wheel blocks shall be drilled from the end of the block midway between the center and outside. When a faished wheel is used, the sample shall bo obtained from the rim face or the bub in a manner which will not impair the usefulness of the wheel. No drilling of the finished wheel plate shall be permitted. Each sample from any one block or wheel shall be thoroughly mixed together and shall be clean, and free from scale, oil and other foreign substances.

\section{Patsrcar Requtraments}

9. Brimell Eardaess.-(a) The hardness of the rim, when measured in accordance with the requirements of Section 9 (b) shall show the following values:

$\begin{array}{cll} & \text { Minimum } & \text { Maximum } \\ \text { Clase } & \text { Hardness } & \text { Hardness } \\ \text { A } & 255 \mathrm{BHN} & 321 \mathrm{BHN} \\ \mathrm{B} & 277 \mathrm{BHN} & 341 \mathrm{BH} \\ \mathrm{C} & 32 ! \mathrm{BH.V} & 3 n 3 \mathrm{BH}\end{array}$

(b) Method of Measurement.- Meamrement shall be made on the front fsce of the rim with the edge of the impreswion not less ths $3 \%$ inch from the ractiu joining facs and tread. Before making the impression, any decarbur-

$$
A-1970
$$


ized metal shall be removed from the front face of the rim at the point chosen for measurement. The suriace of the wheel rim ahall be properly prepared to permit accurate determination of hardsess.

(c) Hub Hardness. - When so specified in order to facilitate machining, the maximum hardness on bub face of wheels which are entirely quenched shall not exceed 293 BHN at any point not more then $3 / 2$ inch from bore.

10. Number of Tests.-(a) Where continuous heat tresting furnaces are used, Brinell hardness mearurements ehall be mode on 10 per cent of the wheels from cach heat. Where batch type hest treating furnaces are used, Brinell hardness messurements shall be made on 10 per cent of the wheels from each heat treaiment lot, provided that at least one (1) wheel is selected for test from esch heat represented in the hest treatment lot. For either process, when there are less than twenty (20) wheeis from a hest, a minimum of two (2) wheels shall be checked for hardoess except wen there is only one (1) wheel from a heat, in which case 3 Bricell hardress measurement shall be made on the ore wheel.

(b) If all the wheels testod meet the requirements of Section 9, all of the wheels represented shall be accepted.

(c) If any wheel tested fails to meet the requirements of Section 9, it shall be checked by making two (2) additional kardness measurements, one on each side of the point frst messured and esci spproximately 1 inch from that point. If both of these check mesrurements meer the requirements of Section 9 , the wheel shall be considered to have met the requirements of Section 9 .

(d) When continuous beat treating furnaces are used, should any of the wheels tested fail on check test to meet the requirements of Section 9, the manuisacturer may test for individual bardness meazurements all of the wheels of that heat in the lot submitted for inspection and those meeting the requirements of Section $\$$ sinall be accepted. There batch beat treating fumaces are used, should any of the wheels tested fail on caecis test to meet the requirements of Section.9, the manufacturer may test all of the wheels in the heat treatment lot for individual hardness measirement and those meeting the requirements of Section 2 shall be accepter.

11. Retreatront.-Any pheel friling to meet the requiremeats of Section 9, may be retreated and tested in accordance with Section 10.

\section{Matevg}

12. Mating. - Wheels shall be measured and marked to one-half tape sizes and shipped in pairs of the same measured tape size.

\section{Peramssibla Vartattons in Demersions}

13. Gages.-The gages and tapes shall conionn to and be used as required by the Standards of the Mechanical Divisios, Aveciation of American Rsilfrosd.

14 Permisaible Veriations-(a) The wheels shall conform to the dimenzions with tolerances as specified in Section G-Wheels, is the A.A.R. Manual of Standards and Recommended Practices.

(b) Where the individual design sheets allow a certain per cent of the wheels to vary from standard dimensions for tape size by a given amount, the percentage of such wheels shipped by any manufacturer shall not exceed this per cent during a calendar year. No individual purchaser may receive more than this per cent of nis daiiy sinipments of such wheels except by agreement with the manuiacturer.

$$
\text { A-1970 }
$$


Frvisa

15. Finish-(a) Wheels ahall be rough bored and shall not bave black spots in the rough bore. Front hub face of rheels (1-W, 2-W and $\mathrm{IWW}$ ) shail be parallel to the plane of the vertical reference line and may be smooth forged or machined. The back hub face may be amooth forged or machined.

(b) The contour of tread and flange sball be as shown in the A.A.R. Manual of Standards and Recommended Practices and shall be machined and Gnished smooth without excessive tool chatters.

(c) Wheels shall be" given a thorough surface examination and ganing at the place of manufacture before being offered for inspection. They shall have a workmanlike finish and must be free from defects liable to develop in or cause removal from service. "As forged" surfaces shall be free of abrupt changes in section or grooves and in a clean condition free of scale prior to final inspection. Where corrective machining or grinding has been employed such surfaces shali not exceed a roughness of 500 microinches, and a umiform transition from the machined or ground surface into the plane of the "as forged" surface must be provided.

(d) Wheels shall not be covered with any substance to such an extent as to bide defects.

(e) Supplementary requirement S-1 ahsll only apply when the removal of mill scale frow the wheel is to be done by the manufacturer.

\section{Marring}

16. Marking.-(a) ILentification markings shall be lezibly hot stampel on the back rim face as shown in Fig. 1. When the original hot stamping on wheels for freight service is removed it shall be cold stamped on the lack hub face as shown in Fig. 2. Repairs to illegible hot stamped characters may be made by cold stamping. Passenger car and locomotive wheels may be hot or cold stamped on the back rim face. At the option of the purchaser locomotive wheels may be cold stamped on the front hub as shown in Fig. 2.

(b) The tape size of all wheels shall be stencilled on back plates with chrome yellow paint in characters at least one inch high. 
I.rSPECTION AVD Rerectiov

17. Inspection. - (4) The inspector representiog the purchaser shail have free entry, at all times while the work on the contract of the purchaser is being performed, to all parts of the manufacturer's works which concern the manufacture of wheels ordered. The manufacturer shall añord the inspector, free of charge, all resonable facilities and necessary asisistance to satisiy him that the whesly are being furnished in accordance with these specifications. Defects not readily visible to the unsided eye are usuaily detected by ultrasonic testing. Such test shall be used in the manufacture of all wheels as a port of mill qusiity control procedures. Tests and inspection snsil be made at place of manuf acture prior to shipment, unless otherwise specified.

(b) The purchaser may make tests to govern the acceptance or rejection of the wheels in his own laboratory or elsewhere. Such tests shall be made at the expense of the purchsser.

(c) All tests and inspoction sball be so conducted as not to interfere unnecessarily with the operation of the works.

18. Rejection.-(s) Wheels represented by samples which fail to conform to the requirements of these specifcations will be rejected.

(b) Wheels which show injurious defects subsequent to original inspection and acceptance at the manuiacturer's morks, or elsewhere, will be rejected, and the manufacturer shall be notified.

19. Rehearing.- Samples tested in accordance with this specification, which represent rejected wheels, shall be held for a period of fourteen (14) dsys from date of the test report. In case of dissatisiaction with the results of the tests, the macufacturer may make claim ior a rehearing within that time.

\section{SUPPLEMENTART REQTEREMENTS}

The following supplementary requirements shall apply only when specified by the purchsser. Details shall be agreed upon by the manufacturer and the purchaser.

S1- Wheels for use under locomotives other than steam shall have all mill scale removed from the entire wheel prior to find inepection. 
MARKING OF WROUGHT STEEL WHEELS-RIMI STAMIPING

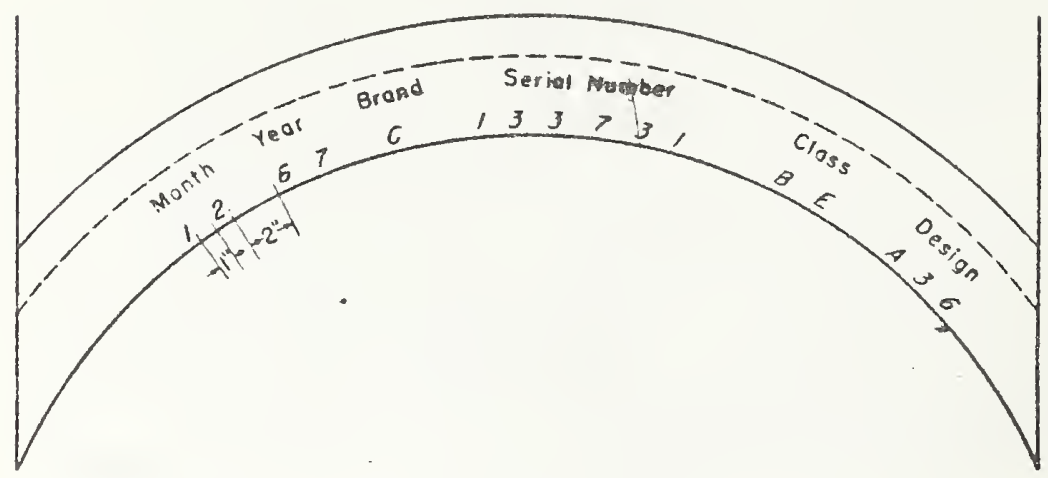

Note 1. Stamping to consist of date of manufacture, brand of mufacturer, manufacturer's ser!al number, class and type of heat treatrent if neac treated and design designation. Stamping on locomotive theels is 1 imited to 13 charactess and the design designation shall be stencilled on the beck plate witn chrome yellow

Noto 2. Stampings to be spaced a minimum of one inch between characters and two inches between groups, lacated not less than $1 / 8$ inch from inner edge of $\mathrm{rim}$. On locomotive mols the staming shall be located not less than $1 / 4$ inch from the inner edge of the rim.

Hote 3. Brand limited to one initial: A-Armco; B-Bethtehen; C-Carnegie (Pitisourgn Plant). E-Edgewater; G-lllinois (Gary Plant); J-Sumi tomo Metal Industries; P-Steel, Peech
and Tozer; S-Standard; T-Taylor Bros. and Co., LtJ.; Z-Canadian Stsel wheel, Ltd.

Note 4. Dies used to produce charactors shatl bo $1 / 2$ inch noninal heignt at crest and hot stamping shall be nomina'ly $3 / 32$ inch in depth. Italicized cnaraciors (sloced upward co rigint), shall be used.

Note 5. Class markings as follows:
A - Class A, rin treated
$A E$ - Class A, entire theel treater
B - Class B, rim treated
Be - Class antire wneel treated
$C$ - Class C, r Im treated
$C E$ - Class C, entire whoel treated
Untreat ad moels (Class U) are not rar hed for class. 


\section{ALTER.V.ATE WARKING OF WROLGHT STEEL IVHEELS-} HUB STAUPING
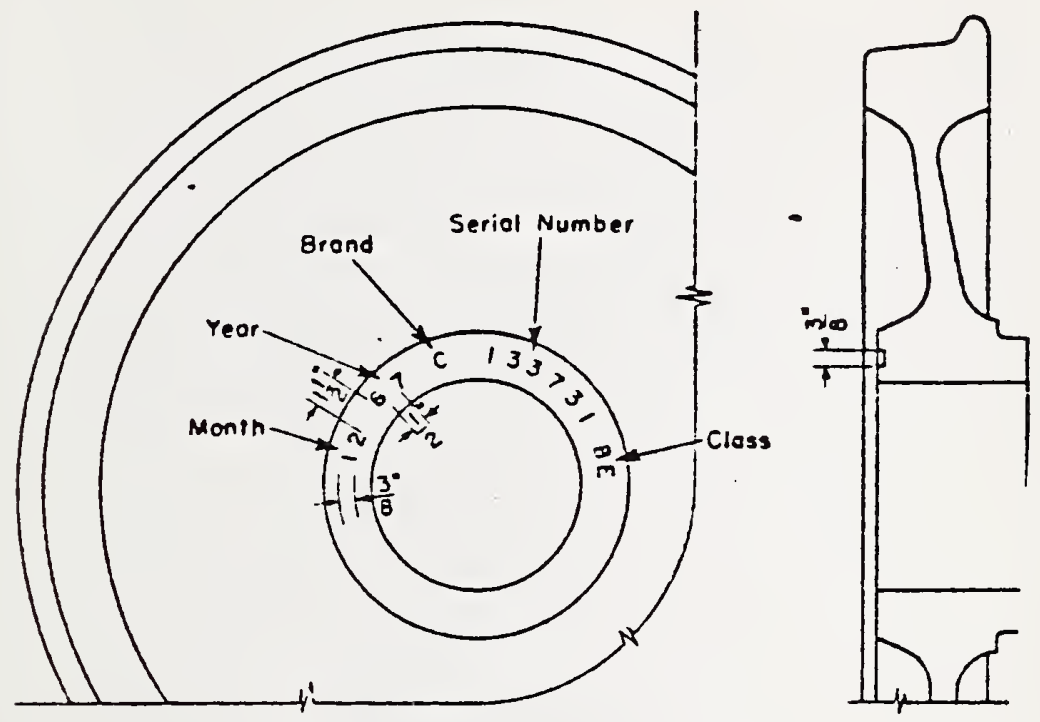

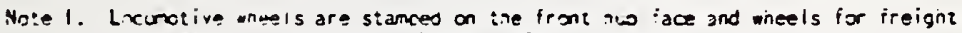
service $a r \geq s$ tamped on tne back nuo face.

No:- 2. Stamping to consist of date of ranufac:ure. Trand oi ranufacturar. Tanufawiurar's serial number, slasj ano iyde si nea: tratrent if neat ireated and desian cesicnation. Stamping on ixcoctice meis is limited to 13 characters and the design designacion siall ze siencilind on the back piate

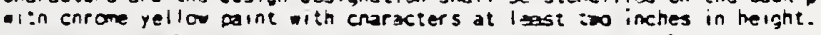

- Ho: 3. Stampings to be soaced aporoximetely $1 / 2$ incon set meen characters and aporox. inateiy $1 / 2,2$ incines between groups and locateo scoraximately censtal of tho hub face.

Wote 4. Stoel stmon usad to oroduce cheracters shall oot be less than $3_{0}$ inch in height.

Note 5. Class carkings as follons:

A - Ciass A, ria treated

$A \varepsilon$ - Class Á, mire med treated

a - Class $\mathrm{s}$, rin treated

- Class S, rin treated

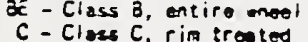

$\mathcal{C E}$ - Clase C, entire meal treat

Untreated theols (Clase U) are not nortad for elass. 



\section{APPENDIX B}

(Specification)

AAR Dimensions for steel wheel of Design $A-40$ and Permissible variations in Dimensions not shown by Tolerances on Individual Design Sheets. 



\section{STEEL WHEEL A-40}

\section{Standard}

ADOPTED, 1946

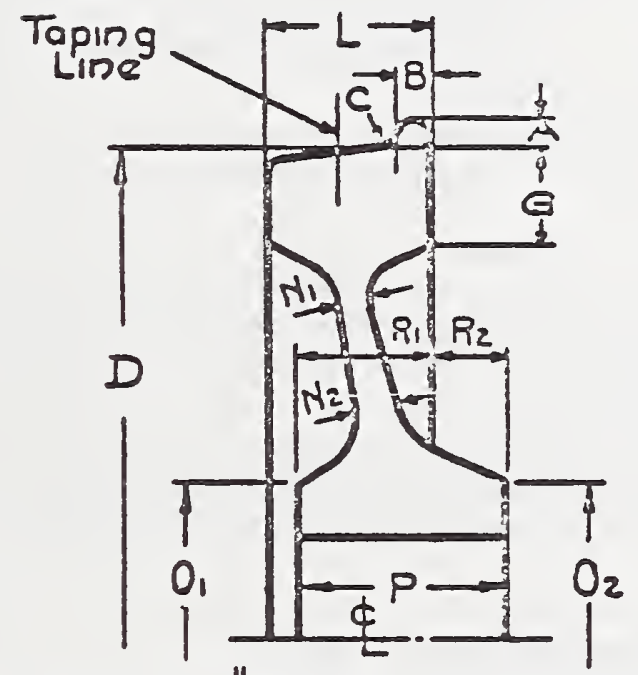

Standard 40"Diesel Locomotive Wheal

Dimensions

2.

Tolerances

\section{Notes}

See page G-27 for permissible variations in dimensions not shown by above tolerances.

\begin{tabular}{|c|c|}
\hline A & 106 \\
\hline$B$ & 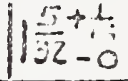 \\
\hline C & $\frac{11+16}{15}$ \\
\hline$D$ & $\sqrt{10}=$ \\
\hline$G$ & $2 \frac{1}{2}$ inin \\
\hline$L$ & $5 \frac{1}{2}$ \\
\hline$N_{1}$ & limin. \\
\hline$N_{2}$ & 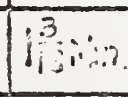 \\
\hline $0_{1}$ & $13 \frac{1}{2}-1$ \\
\hline $\mathrm{O}_{2}$ & $13 \frac{1}{2}-0$ \\
\hline$P$ & $6 \frac{1}{2} \div \frac{1}{3}$ \\
\hline$R_{1}$ & $4010+\frac{1}{30}$ \\
\hline$R_{2}$ & $1 ! f$ \\
\hline $\begin{array}{l}\text { Max } \\
\text { Finish } \\
\text { Bore } \\
\end{array}$ & $10 \%$ \\
\hline $\begin{array}{l}\text { Min } \\
\text { Wub } \\
\text { wall } \\
\end{array}$ & 13 \\
\hline
\end{tabular}




\section{PERMISSIBLE VARLATIONS IN DIMENSIONS NOT SHOWN BY TOLERANCES ON INDIVIDUAL DESIGN SHEETS}

1. Inside Diameter-Back Face of Rim.-The inside diameter of the rim at the baek face of the wheel shall not vary more than $3 / 8$ in. under the nominal dimension. The maximum diameter at this loeation is governed by the rim thiekness and the tape size.

2. Inside Diameter-Front Face of Rim.-For narrow flangc wheels, the inside diameter of the rim at the front face of the wheel shall not exceed that at the back face of the whecl and shall not vary under this dimension by more than $1 / 4$ in. For wide flange wheels, the inside diannet of the rim at the front fare of the wheel shall not differ from that at the back face of the wheel by more than $/ 4$ in.

3. Thickness of Rim.-In any wheel the radial thiekness of the rim shall not vary more than $1 / 8$ in. around the wheel.

4. Corner at Inside Diameter of Back Face.-A sharp corner is preferable to faeititate measurement. In any ease the radius of the corner shall not exceed $1 / 8$ in.

5. Plane of Back Face.-When wheels are gaged with a straight edge applied to back fare of rim, no point on back facc of narrow flunge wherls more than $1 \frac{1}{4} \mathrm{in}$. from inside edize of $\mathrm{im}$ shall be more than $1 / 32 \mathrm{in}$. from the atraight edge. For wile flange wheels, no point on back face of rim shall be more than $1 / 16$ in. from straight edge.

6. Hub Wall Thickness. - The thiekness of the hub wall in any one wheel measured at any two points equidistant from the face of the bub shall not vary by more than $3 / 8$ in. if the hub is not machined, nor by more than $1 / 8$ in. if the hub is maehined.

7. Rotundity.-Tread when gaged with a ring gage must not bave opening between tread and gage at any point over $1 / 32$ in.

8. Diameter of Bore.- The diameter of rough bore shall not vary more than $1 / 6$ in. over, nor more than $1 / 8$ in. under the dimensions spccified. The specified rough bore shall be at least 1, in. less in diameter thun the tinished bore, subject to $1 / 16 \mathrm{in}$. toleranee and/or $1 / 8 \mathrm{in}$. under the diameter specified.

9. Eccentricity Bore.-Eceentricity between the rough bore and tread measured in the plane of the taping linc shall not excert $i_{k}$ in.

NOTE.-Where dimension $R_{1}$ and $R$, is marked f extrs atock of $3 / 4$ to 3 in inches over specifed dimension may be ieft for machining of each fnished eurface or wheel may be furnished faished to eract dimension shown. Hub length tolerance is based on finished dimension. 
NBS.114A IREV. 7.031

\begin{tabular}{|c|c|c|c|}
\hline $\begin{array}{l}\text { U.S. DEPT. OF SOMA. } \\
\text { BIBLIOGRAPHIC DATA } \\
\text { SHEFT }\end{array}$ & 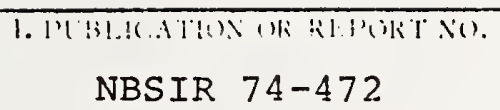 & $\begin{array}{l}\text { 2. wov't decession } \\
\text { No. }\end{array}$ & 3. Recipient's Accension N.) \\
\hline \multirow{2}{*}{\multicolumn{3}{|c|}{$\begin{array}{l}\text { 4. TITIE ANI IIIII } \\
\text { ANALYSIS OF RAILROAD WHEEL FAILURE - DERAILMENT } \\
\text { AT RICHMOND HILI, NEW YORK, MARCH 10, } 1973 .\end{array}$}} & $\begin{array}{l}\text { 5. Publication 1).4e } \\
\text { Apri1 } 1974\end{array}$ \\
\hline & & & 6. Pcrforming Orgunizattion Coric \\
\hline \multirow{3}{*}{\multicolumn{3}{|c|}{ 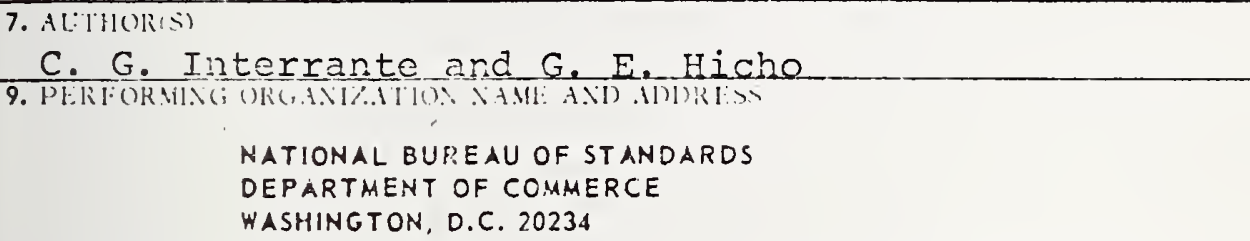 }} & $\begin{array}{l}\text { 8. Performing Orpan. Report } \mathrm{N} \text {. } \\
\text { NBSIR } 74-472\end{array}$ \\
\hline & & & 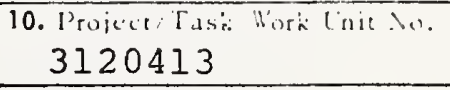 \\
\hline & & & 11. Contract Grant No. \\
\hline \multirow{2}{*}{\multicolumn{3}{|c|}{$\begin{array}{l}\text { 12. Sponsoring Orgunization N.ume and Complete Aduress Strect, City. Stat } \\
\text { Federal Railroad Aaministration } \\
\text { Department of Transportation } \\
\text { Washingtor, D. C. } 20590\end{array}$}} & $\begin{array}{l}\text { 13. Type of Repurt \& Perioi } \\
\text { Covered Failure }\end{array}$ \\
\hline & & & 14. Sponsoring Agency Cuide \\
\hline
\end{tabular}

16. AlSTRACT (A 200-word or less factual summary oi most sifnificant in ímation. If document includes a significant bibliographv or literature survey. mention "here.)

At the request of the Standards and Procedures Division, Federal Railroad Administration, Department of Transportation, a failure analysis was made of a section of a railroad wheel which had reportedly failed in service and had led to a derailment at Pichmond Hill, New York. A section of the failed wheel was sent to NBS where it was examined and measurements made to determine the cause of the failure and to determine whether or not the wheel had been produced in accordance with applicable specifications.

The chemical composition, hardness, and dimensions of the wheel section were measured. The results indicate that the wheel met the requirements of the specifications. These measurements and other observations indicate that the failure occurred as a result of local overheating at the front of the tread. It is believed that this overheating occurred in service and resulted in the formation of a thermal crack in this region. This crack subsequently propagated rapidly in a radial direction through to the hub of the wheel.

17. KEY UORDS (six to twelve entries; alphabetical order; capitalize only the first letter of the first key word unless a proper name; separated by semicolons)

Chemical composition; failure analysis; fracture characteristics; hardness, railroad wheel.
18. AVAILABILITY

ए Unlimited

For Official Distribution. Do Not Release to NTIS

Order From Sup of Due., U.S. Government Printing Ofíice Washington, D.C. 20.102, Sil) Car. Nu.C.13

- Order lirum Narional Technical Information Service (NTIS) sprinpficld. Virgini. 2:151

\begin{tabular}{|l|c|}
\hline $\begin{array}{l}\text { 19. SECURITY CL.ASS } \\
\text { (THIS REPURT) }\end{array}$ & 21. NO. OF P.AGES \\
UNCL ASSIFIED & 42 \\
\hline $\begin{array}{l}\text { 20. SE(CURITY CLASS } \\
\text { (THIS PAGE) } \\
\text { UNCLASSIFIED }\end{array}$ & 22. Price \\
\hline
\end{tabular}





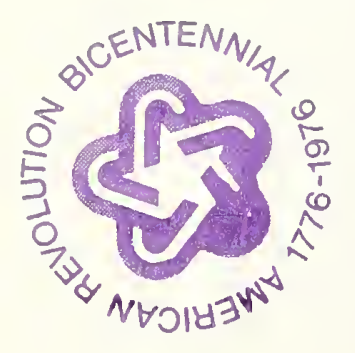

